\title{
$\widehat{A M} \mid$ SCHOOL OFLAW

Volume 2 | Issue 2

2014

Resoling International Shoe

Donald L. Doernberg

Follow this and additional works at: https://scholarship.law.tamu.edu/lawreview

Part of the Law Commons

\section{Recommended Citation}

Donald L. Doernberg, Resoling International Shoe, 2 Tex. A\&M L. Rev. 247 (2014).

Available at: https://doi.org/10.37419/LR.V2.I2.3

This Article is brought to you for free and open access by Texas A\&M Law Scholarship. It has been accepted for inclusion in Texas A\&M Law Review by an authorized editor of Texas A\&M Law Scholarship. For more information, please contact aretteen@law.tamu.edu. 


\title{
RESOLING INTERNATIONAL SHOE
}

\author{
Donald L. Doernberg* \\ TABle of Contents
}

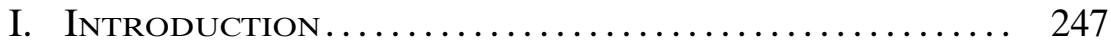

II. Dropping the Shoe: Corporate "Presence"

Overtakes Minimum Contacts ................ 256

A. Pennoyer Procrusteanism ................... 256

B. Breaking Pennoyer's Bonds ................ 260

III. General Jurisdiction Over Corporations ........ 261

A. Enter Goodyear.......................... 264

B. Daimler.................................. 266

C. General Jurisdiction over Corporations: The Empty

Record ................................. 270

D. Scholarship on General Jurisdiction ............. 272

IV. Whither International Shoe's Theory? .......... 275

V. Dropping the Other Shoe: Goodyear's AND DAIMLER'S IMPLICATIONS AND BURNHAM'S FLAT

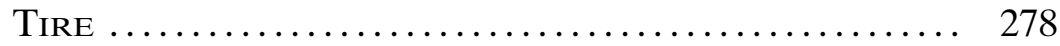

A. General Jurisdiction over the Individual.......... 290

B. General Jurisdiction over the Corporation.......... 290

VI. Conclusion ................................ 296

\section{INTRODUCTION}

Something has got to give. The Supreme Court has retreated from more than seven decades of personal jurisdiction analysis. After Goodyear Dunlop Tires Operations, S.A. v. Brown, the Court's jurisprudence of general jurisdiction ${ }^{1}$ looked like an M.C. Escher print. ${ }^{2}$ If

* Professor of Law, Pace University School of Law. B.A., Yale University 1966; J.D. Columbia University 1969. I am grateful to my colleagues at Pace for their participation in a colloquium on August 6, 2013, and for their penetrating questions and observations. My treasured colleague Michelle Simon and my wife Cyndy Pope were generous with their time reading and commenting on earlier drafts. I am indebted also for the fine research assistance that Cassia Horvitz and Cristina Riggio, Class of 2015, and Elizabeth Perreca and Jacob Barnett Sher, Class of 2016, provided. Ms. Perreca and Mr. Sher also proved to be exceptionally demanding editors - the best kind. Special thanks to Texas A\&M Articles Editors Whitley Zachary and Matthew McGowan; this article is far better for their efforts, and I would have immensely enjoyed working with them in a teacher-student relationship. (2011).

1. See Goodyear Dunlop Tires Operations, S.A. v. Brown, 131 S. Ct. 2846, 2853

First, as in International Shoe itself, jurisdiction unquestionably could be asserted where the corporation's in-state activity is "continuous and systematic" and that activity gave rise to the episode-in-suit. Further, the Court observed, the commission of certain "single or occasional acts" in a State may be sufficient to render a corporation answerable in that State with respect to those acts, though not with respect to matters unrelated to the fo-

DOI: https://doi.org/10.37419/LR.V2.I2.3 
read fast enough, it appeared to make sense. Closer examination reveals an intellectual structure as impossible as anything that Escher could have drawn. ${ }^{3}$ Then the Court made it worse in Daimler AG v. Bauman. ${ }^{4}$ The Court seemingly has begun a project to rein in what it now regards as states' unreasonable (and therefore unconstitutional) assertions of general jurisdiction over corporations. It has implicitly backed away from some of International Shoe's ${ }^{5}$ minimum-contacts analysis that dominated the law of constitutional personal jurisdiction since 1945. Goodyear and Daimler create a far more restrictive concept of corporate presence. If the Court purports to retain International Shoe's principle that jurisdictional exercises be fair and

rum connections. The heading courts today use to encompass these two International Shoe categories is "specific jurisdiction." Adjudicatory authority is "specific" when the suit "aris[es] out of or relate[s] to the defendant's contacts with the forum.

International Shoe distinguished from cases that fit within the "specific jurisdiction" categories, "instances in which the continuous corporate operations within a state [are] so substantial and of such a nature as to justify suit against it on causes of action arising from dealings entirely distinct from those activities." Adjudicatory authority so grounded is today called "general jurisdiction."

Id. at 2853 (citations omitted). General jurisdiction has limits, however. A court may have general jurisdiction over a defendant, yet it cannot enter an order directly affecting the defendant's real property located outside the state. See, e.g., Fall v. Eastin, 215 U.S. 1 (1909). Fall, though old, is still good law, but one must recognize its limitations. The rendering court may not itself (or through a court-appointed agent such as a commissioner, as in Fall) execute a deed to property in another state. It can, however, order the defendant-owner of the property to execute the deed and enforce the order with the contempt power. Such an order is also enforceable in other states. See Pennoyer v. Neff, 95 U.S. 714, 723 (1877); Restatement (SECONd) of Conflict of Laws $§ 102$ (1971); id. cmt. d; id. Reporter's Note to cmt. d.

2. M.C. Escher was a graphic artist. One of his areas of expertise was drawing the "impossible structure"-a picture that looked real upon first glance but that closer study revealed to be a physical impossibility.

With Escher, optical illusion is achieved by means of a representational logic that hardly anyone can evade. By his method of drawing, by his composition, he "proves" the genuineness of the suggestion that he has brought into being. And the fascinated viewer, on coming to his senses, realizes that he has been taken in. Escher has literally conjured up something before his eyes. He has held before him a magic mirror whose spell has been cast as a compelling necessity. In this Escher is an absolute master and unique at that.

The Magic Mirror of M.C. Escher 6 (Bruno Ernst, ed. 1994). E.g., Donald L. Doernberg, What's Wrong with This Picture?: Rule Interpleader, the Anti-Injunction Act, In Personam Jurisdiction, and M.C. Escher, 67 Colo. L. Rev. 551, 551 (1996).

3. I am not the only one with this view. Commenting on the Court's decisions in Goodyear and J. McIntyre Machinery, Ltd. v. Nicastro, Professor Borchers said simply, "The Supreme Court performed miserably," although he did allow that Goodyear was "not nearly as bad" as J. McIntyre. Patrick J. Borchers, J. McIntyre Machinery, Goodyear, and the Incoherence of the Minimum Contacts Test, 44 CREIGHTON L. Rev. 1245, 1245 (2011).

4. Daimler, AG v. Bauman, 134 S. Ct. 746 (2014).

5. Int'l Shoe Co. v. Washington, 326 U.S. 310 (1945). 
reasonable, ${ }^{6}$ it has implicitly but unmistakably undermined a jurisdictional basis that long antedates International Shoe and that the Court unanimously reaffirmed only two decades ago in Burnham v. Superior Court-individuals' receipt of service of process while in the forum. ${ }^{7}$

International Shoe set out four basic patterns of jurisdictional concern along two axes. On one axis, the Court considered the defendant's contacts with the forum, which could be "continuous and systematic" dressed whether the plaintiff's claim arose from the defendant's instate activities ${ }^{10}$ or was unrelated. ${ }^{11}$ Thus, there were four patterns into which cases might, at least preliminarily, fit: (1) systematic and continuous contacts and a related claim, ${ }^{12}(2)$ systematic and continuous contacts and an unrelated claim, ${ }^{13}(3)$ isolated contacts and a related claim, ${ }^{14}$ and (4) isolated contacts and an unrelated claim. ${ }^{15}$ The last category has not yielded jurisdiction, with one important exception: service of process upon an individual within the forum allows the forum to exercise personal jurisdiction, even with respect to claims having no forum relationship and even if the individual has no other forum contacts. ${ }^{16}$ The first and third patterns give rise to "specific

6. Id. at 316 (quoting Milliken v. Meyer, 311 U.S. 457, 463 (1940) ("[M]inimum contacts such that the maintenance of the suit does not offend 'traditional notions of fair play and substantial justice." ").

7. I refer here to jurisdiction over an individual based simply on service of the summons within the forum. See Burnham v. Superior Court, 495 U.S. 604 (1990).

8. Id. at 317; see also id. at 320 ("systematic and continuous"). "[T] here have been instances in which the continuous corporate operations within a state were thought so substantial and of such a nature as to justify suit against it on causes of action arising from dealings entirely distinct from those activities." Id. at 318.

9. Id. at 317 .

10. Id.

11. $I d$.

12. See, e.g., id.

13. See, e.g., Perkins v. Benguet Consol. Mining Co., 342 U.S. 437, 445 (1952); Bryant v. Finnish Nat'l Airline, 208 N.E.2d 439, 440 (N.Y. 1965); Tauza v. Susquehanna Coal Co., 115 N.E. 915, 917 (N.Y. 1917).

14. See, e.g., McGee v. Int'l Life Ins. Co., 355 U.S. 220, 221 (1957); Hess v. Pawloski, 274 U.S. 352, 356 (1927).

15. See, e.g., Ratliff v. Cooper Labs., Inc., 444 F.2d 745, 745-46 (4th Cir. 1971). I refer to these patterns as Categories 1 through 4, respectively. With respect to Category 2, jurisdiction over corporations, the International Shoe Court noted, "To require the corporation in such circumstances to defend the suit away from its home or other jurisdiction where it carries on more substantial activities has been thought to lay too great and unreasonable a burden on the corporation to comport with due process." Int'l Shoe Co. v. Washington, 326 U.S. 310, 317 (1945) (emphasis added). The distinction the International Shoe Court made between the corporate "home" and other forums where exercising jurisdiction would be constitutionally reasonable, becomes quite important when considering Goodyear and Daimler. See infra Part II.

16. See, e.g., Burnham v. Superior Court, 495 U.S. 604 (1990); Pennoyer v. Neff, 95 U.S. 714 (1877). Although the Burnham Court was unanimous in its conclusion that jurisdiction existed, there was no majority opinion and no majority theory supporting the conclusion. Burnham, 495 U.S. 604 (1990). The real importance of Burnham lies not in its result, but in the titanic clash between Justices Brennan and Scalia on meth- 
jurisdiction," while the second pattern concerns "general jurisdiction." 17

Before International Shoe, states exercised general jurisdiction over corporations. In Tauza v. Susquehanna Coal Co., for example, Judge Cardozo carefully recited the connections that Susquehanna Coal (a Pennsylvania corporation) had with the state that allowed jurisdiction. ${ }^{18} \mathrm{He}$ also listed contacts that the defendant could have had but did not. ${ }^{19}$ His opinion told the reader nothing about the plaintiff's claim save that "the jurisdiction does not fail because the cause of action sued upon has no relation in its origin to the business here transacted." 20 Referring to defendant's coal shipments to New York, he observed:

They are made in response to orders transmitted from customers in New York. They are made, not on isolated occasions, but as part of an established course of business. In brief, the defendant maintains an office in this state under the direction of a sales agent, with eight salesmen, and with clerical assistance, and through these agencies systematically and regularly solicits and obtains orders which result in continuous shipments from Pennsylvania to New York.

To do these things is to do business within this state in such a sense and in such a degree as to subject the corporation doing them to the jurisdiction of our courts. ${ }^{21}$

ods of constitutional interpretation more generally. Compare id. at 622-27 (Scalia, J., concurring in the judgment), with $i d$. at 629-37 (Brennan, J., concurring in the judgment).

17. See supra notes $12-15$, and accompanying text.

18. Tauza, 115 N.E. at 916.

The defendant's principal office is in Philadelphia; but it has a branch office in New York, which is in charge of one Peterson. Peterson's duties are described by the defendant as those of a sales agent. He has eight salesmen under him, who are subject to his orders. A suite of offices is maintained in the Equitable Building in the city of New York, and there the sales agent and his subordinates make their headquarters. The sign on the door is "Susquehanna Coal Company, Walter Peterson, Sales Agent." The offices contain eleven desks, and other suitable equipment. In addition to the salesmen there are other employés, presumably stenographers and clerks. The salesId. men meet daily and receive instructions from their superior.

19. $I d$. at $916-17$.

All sales in New York are subject, however, to confirmation by the home office in Philadelphia. The duty of Peterson and his subordinates is to procure orders which are not binding until approved. All payments are made by customers to the treasurer in Philadelphia; the salesmen are without authority to receive or indorse checks. A bank account in the name of the company is kept in New York, and is subject to Peterson's control, but the payments made from it are for the salaries of employés, and for petty cash disbursements incidental to the maintenance of the office. The defendant's Id. coalyards are in Pennsylvania, and from there its shipments are made.

20. Id. at 918 .

21. Id. at 917 . 
Operating under the restrictive rubric of Pennoyer $v$. Neff, ${ }^{22}$ Judge Cardozo concluded that "[a]ll that is requisite is that enough be done to enable us to say that the corporation is here .... If it is here it may be served." 23 Thus, the Pennoyer basis supporting jurisdiction was service of process on the defendant within the forum - in effect, transient jurisdiction over a corporation.

International Shoe cited Tauza as an appropriate example of general jurisdiction over a corporation. ${ }^{24}$ But the Court, borrowing reasoning from Judge Learned Hand, ${ }^{25}$ explicitly repudiated the analysis that Tauza (following the Supreme Court's lead) ${ }^{26}$ had used to reach that result:

Since the corporate personality is a fiction, although a fiction intended to be acted upon as though it were a fact, ... it is clear that unlike an individual its "presence" without, as well as within, the state of its origin can be manifested only by activities carried on in its behalf by those who are authorized to act for it. To say that the corporation is so far "present" there as to satisfy due process requirements, for purposes of taxation or the maintenance of suits against it in the courts of the state, is to beg the question to be decided. For the terms "present" or "presence" are used merely to

22. See Pennoyer v. Neff, 95 U.S. 714, 723 (1877).

23. Tauza, 115 N.E. at 918 (citing St. Louis Sw. Ry. Co. of Tex. v. Alexander, 227 U. S. 218 (1913); Wash.-Va. Ry. Co. v. Real Estate Trust Co. of Phila., 238 U.S. 185

(1915); Int'l Harvester Co. of Am. v. Kentucky, 234 U.S. 579 (1914)).

24. Int'l Shoe Co. v. Washington, 326 U.S. 310, 318 (1945).

25. Id. at 317 (citing Hutchinson v. Chase \& Gilbert, Inc., 45 F.2d 139, 141 (2d. Cir. 1930)). In Hutchinson, the Court said:

It scarcely advances the argument to say that a corporation must be "present" in the foreign state, if we define that word as demanding such dealings as will subject it to jurisdiction, for then it does no more than put the question to be answered. Indeed, it is doubtful whether it helps much in any event. It is difficult, to us it seems impossible, to impute the idea of locality to a corporation, except by virtue of those acts which realize its purposes. The shareholders, officers and agents are not individually the corporation, and do not carry it with them in all their legal transactions. It is only when engaged upon its affairs that they can be said to represent it, and we can see no qualitative distinction between one part of its doings and another, so they carry out the common plan. If we are to attribute locality to it at all, it must be equally present wherever any part of its work goes on, as much in the little as in the great.

When we say, therefore, that a corporation may be sued only where it is "present," we understand that the word is used, not literally, but as shorthand for something else. It might indeed be argued that it must stand suit upon any controversy arising out of a legal transaction entered into where the suit was brought, but that would impose upon it too severe a burden. On the other hand, it is not plain that it ought not, upon proper notice, to defend suits arising out of foreign transactions, if it conducts a continuous business in the state of the forum.

Hutchinson, 45 F.2d at 141 (emphasis added). The "something else" of which Judge Hand spoke was what the Supreme Court would later call "minimum contacts." See, e.g., Int'l Shoe, 326 U.S. at 316.

26. See supra note 23. 
symbolize those activities of the corporation's agent within the state which courts will deem to be sufficient to satisfy the demands of due process. ${ }^{27}$

Nonetheless, corporate "presence" and the related concept of systematic and continuous activities remained alive and well as jurisdictional predicates long after International Shoe. ${ }^{28}$ Even the Court has not been immune to making such references. ${ }^{29}$

Ironically, though International Shoe disapproved the questionbegging concept of corporate "presence," Goodyear and Daimler reinstituted it and used it to narrow the general jurisdiction that International Shoe approved. ${ }^{30}$ "Home" is, after all, a geographical and legal term of location. Goodyear and Daimler are irreconcilable with International Shoe's minimum-contacts approach. Daimler is a bit disingenuous with respect to that foundation case. The Court observed:

International Shoe distinguished between . . . exercises of specific jurisdiction ... situations where a foreign corporation's "continuous corporate operations within a state [are] so substantial and of such a nature as to justify suit against it on causes of action arising from

27. Int'l Shoe, 326 U.S. at 316-17; see also Carol Andrews, Another Look at General Jurisdiction, 47 WAKE Forest L. Rev. 999, 1007 (2012) ("The Court discarded both the consent and presence theories as unnecessary fictions."). Note, however, that even International Shoe referred to a corporation's "home." See Int'l Shoe, 326 U.S. at 317.

International Shoe may have discarded presence theory as unnecessary shorthand, but other courts continue to regard it as useful, for discussion of corporate presence continues. The states understood International Shoe to have expanded, not restricted, available jurisdiction over corporations; courts understand it not as a repudiation of "presence" jurisdiction so much as a change in vocabulary. See, e.g., Purdue Research Found. v. Sanofi-Synthelabo, S.A., 338 F.3d 773, 787 (2003) (constructive presence of corporation); Philadelphia v. Borough of Westville, 93 A.3d 530, 533-34 (2014); Landoil Res. Corp. v. Alexander \& Alexander Servs., Inc., 565 N.E.2d 488, 490 (1990); Simonson v. Int'l Bank, 200 N.E.2d 427, 430 (N.Y. 1961); Morgan, Lewis \& Bockius LLP v. East Chicago, 934 N.E.2d 23, 30-31 (Ill. App. Ct. 2010) (presence).

28. See, e.g., Landoil Res. Corp. v. Alexander \& Alexander Servs., Inc., 918 F.2d 1039, 1043-44 (2d Cir. 1990) (presence); Hunt v. Erie Ins. Grp., 728 F.2d 1244, 1246 (9th Cir. 1984) (substantial and continuous); Kirkpatrick v. Rays Grp., 71 F. Supp. 2d 204, 217 (W.D.N.Y. 1999) (presence); Borough of Westville, 93 A.3d at 533 (continuous and systematic); Nationwide Contractor Audit Serv., Inc. v. Nat'l Compliance Mgmt. Servs., Inc., 622 F. Supp. 2d 276, 283 (W.D. Pa. 2008) (continuous and systematic); Delagi v. Volkswagenwerk AG, 278 N.E.2d 895, 896 (N.Y. 1972) (presence). See also James R. Pielemeier, Goodyear Dunlop: A Welcome Refinement of the Language of General Personal Jurisdiction, 16 LewIS \& CLARK L. REv. 969, 981 n.81 (2012) (citing additional cases); id. at 982 ("Other courts appear to require some sort of continuous physical business presence. ...") (citing cases).

29. See, e.g., Daimler, AG v. Bauman, 134 S. Ct. 746, 754 (2014) ("essentially at home") (quoting Goodyear Dunlop Tires Operations, S.A. v. Brown, 131 S. Ct. 2846, 2853-54 (2011)); Rush v. Savchuk, 444 U.S. 320, 330 (1980) (defendant corporation "found" in every state).

30. See Pielemeier, supra note 28 , at 991 . "[A] limitation of general jurisdiction over corporations to places where they are 'at home,' appears clearly to envision fewer places than one could envision under tests of 'presence,' 'doing business,' and "continuous and systematic general business contacts." I Id. 
dealings entirely distinct from those activities." As we have since explained, "[a] court may assert general jurisdiction over foreign (sister-state or foreign-country) corporations to hear any and all claims against them when their affiliations with the State are so 'continuous and systematic' as to render them essentially at home in the forum State." 31

This analysis ignores the two general-jurisdiction cases involving corporations that the International Shoe Court cited and obviously approved.

Missouri, Kansas \& Texas Railway Co. v. Reynolds ${ }^{32}$ summarily affirmed a state-court judgment resting on the Court's opinion in St. Louis Southwestern Railway Co. v. Alexander. ${ }^{33}$ The court in St. Louis Southwestern Railway ruled that a corporation was "doing business" sufficient to support what we now call general jurisdiction, describing the local office as follows:

Here, then, was an authorized agent . . . undertaking to act for and represent the company, negotiating for it, and in its behalf declining to adjust the claim made against it. In this situation we think this was the transaction of business in behalf of the company by its authorized agent in such manner as to bring it within the District of New York, in which it was sued, and to make it subject to the service of process there. ${ }^{34}$

The bulk of corporate activity occurred outside New York. ${ }^{35}$ The defendant was a Texas corporation apparently doing most of its business in the Midwest. ${ }^{36}$ The Court's recapitulation of the defendant's operations makes clear that New York was not its principal place of business. ${ }^{37}$ Nonetheless, a unanimous Court found that the corporation was "present" in the forum. "38 "Present" it may have been; "at home" it clearly was not.

Tauza, which International Shoe also approved, is similar. The defendant was a Pennsylvania corporation with its principal place of business in Philadelphia. ${ }^{39}$ It had a small continuous operation in New York. $^{40}$ Tauza would have failed the essentially-at-home test of Goodyear and Daimler. Accordingly, today's Court must regard the International Shoe court as wrong, at least in its approval of Tauza and

31. Daimler, 134 S. Ct. at 754 (citing Int'l Shoe, 326 U.S. at 318, and Goodyear Dunlop, 131 S. Ct. at 2853, respectively).

32. Mo., Kan. \& Tex. Ry. Co. v. Reynolds, 255 U.S. 565, 565 (1921) (per curiam).

33. St. Louis Sw. Ry. Co. of Tex. v. Alexander, 227 U.S. 218 (1913).

34. Id. at 228. One should note that the transaction underlying the dispute might have been "related" to the forum in today's terms, but the Court did not invent that concept until International Shoe in 1945.

35. See id. at 224-25 (describing the type and locations of corporate activities).

36. See id. at 224.

37. See id.

38. See id. at 226-28.

39. Tauza v. Susquehanna Coal Co., 115 N.E. 915, 916 (N.Y. 1917).

40. Id. See also supra notes 18-25 and accompanying text. 
St. Louis Southwestern Railway. The International Shoe Court regarded the defendants' forum contacts in Saint Louis Railway and Tauza as sufficient for general jurisdiction. The Goodyear-Daimler Court does not. I differ with Professor Andrews's conclusion that "[t]he Goodyear clarification is not a new standard but is instead the correct reading of International Shoe." ${ }^{41}$ Goodyear articulated a narrower standard and would exclude from general jurisdiction two cases that International Shoe included. ${ }^{42}$

As Justice Sotomayor pointed out in her concurrence, Daimler added a new factor with respect to assertions of general jurisdiction over corporations; ${ }^{43}$ I shall call this factor "relative contacts." General jurisdiction now rests not simply on whether the corporation's contacts are systematic, continuous, and voluminous, but rather on an asyet-vague mathematical relationship that the forum contacts bear to the corporation's total business. Daimler cleared the way to general jurisdiction over a small foreign corporation doing most of its business within the forum while ruling out general jurisdiction over a huge corporation with only a small part of its business in the forum, even though the amount of the latter's forum business may dwarf the former's. ${ }^{44}$

Goodyear's new standard revealed (and Daimler aggravated) a considerable imbalance between corporations and individuals with respect to general jurisdiction. Both cases sharply limited general jurisdiction over corporations; neither spoke of whether Burnham v. Superior Court, which reaffirmed general jurisdiction over individual defendants based merely on service of process in the forum, retained vitality. ${ }^{45}$ Justice Sotomayor raised that question in Daimler, ${ }^{46}$ but the majority ignored the point. ${ }^{47}$ A corporation is now subject to general

41. Andrews, supra note 27, at 1050.

42. Although the parent company Goodyear USA did not contest jurisdiction, perhaps it could have done so successfully. Goodyear Dunlop Tires Operations, S.A. v. Brown, 131 S. Ct. 2846, 2852 (2011). Is Goodyear USA "essentially at home" in North Carolina? According to the corporation's web site, its global headquarters are in Ohio. Worldwide Facilities, GoODYEAR, http://www.goodyear.com/corporate/ab out/facilities.html (last visited Oct. 7, 2014). It has nineteen sites in the United States, only two of which are in North Carolina. Id. In addition, it has three Canadian sites, seventeen European sites, and twenty other sites scattered around the world. Id. It apparently lacks continental sites only in Australia and Antarctica. See id. Ohio issued its corporate charter. Goodyear, $131 \mathrm{~S}$. Ct. at 2850 . It is difficult to conclude that the corporation is "essentially at home" in North Carolina; only two of its sites are there, with the other 57 elsewhere. Id. Perhaps the parent company should have contested jurisdiction, but one should remember that the Court only articulated the relative-contacts approach three years after Goodyear. See Daimler, AG v. Bauman, 134 S. Ct. 746, 762 n.20 (2014). See also infra note 133 and accompanying text.

43. Daimler, AG v. Bauman, 134 S. Ct. 746, 763-64 (2014) (Sotomayor, J., concurring in the judgment).

44. Id. at 772 .

45. See Burnham v. Superior Court, 495 U.S. 604 (1990).

46. See Daimler, 134 S. Ct. at 772-73 (Sotomayor, J., concurring in the judgment).

47. See generally id. 
jurisdiction only in states where it is incorporated, has its principal place of business, or is otherwise "essentially at home." ual remains subject to general jurisdiction in any state in which he receives service of process. ${ }^{49}$ Daimler's relative-contacts approach makes the disparity in analysis far sharper and more troubling than Goodyear did.

If the Court purports to retain International Shoe's minimum-contacts approach, it needs to reexamine two aspects of personal jurisdiction. First, it needs to decide whether huge, multinational corporations are "too big for general jurisdiction," as Justice Sotomayor put it, ${ }^{50}$ while their tinier counterparts remain subject to it with far fewer contacts. ${ }^{51}$ Second, if the quality and quantity of contacts really concern the Court, ${ }^{52}$ it must find a way to reconcile its theory of general jurisdiction over corporations with the idea of transient jurisdiction over individuals. Goodyear and Daimler imply that huge corporations with extensive activities in a forum may not be subject to general jurisdiction except in very restricted (and as yet unclear) circumstances. ${ }^{53}$ In contrast, individuals are exposed to general jurisdiction based only on a few minutes presence in the forum and the happenstance of in-state service. The contacts sufficient to sup-

48. Goodyear, 131 S. Ct. at 2851. Goodyear equated a corporation's states of incorporation and principal place of business with an individual's domicile, making them, in effect, corporate homes for jurisdictional purposes. Id. at 2853-54. There is considerable scholarly debate about what this beguiling phrase actually means. See, e.g., Allan R. Stein, The Meaning of "Essentially at Home" in Goodyear Dunlop, 63 S. C. L. Rev. 527 (2012); Meir Feder, Goodyear, "Home," and the Uncertain Future of Doing Business Jurisdiction, 63 S.C. L. REv. 671 (2012). At least one state supreme court, however, views the phrase as limited to a corporation's states of incorporation and principal place of business. See Viega GmbH v. Eighth Judicial Dist. Court, 328 P.3d 1152, 1158 (Nev. 2014). But see 4 Charles Alan Wright \& Arthur R. Miller, Federal Practice and Procedure, § 1067.5 at 292 (Supp. 2014) ("If the Goodyear opinion stands for anything, aside from the limited proposition that stream of commerce theory is an inappropriate base for general jurisdiction, it simply reaffirms that defendants must have continuous and systematic contacts with the forum in order to be subject to general jurisdiction.").

49. See Burnham v. Superior Court, 495 U.S. 604, 628-29 (1990). In Burnham, Justice Brennan used the label “'transient jurisdiction' to refer to jurisdiction premised solely on the fact that a person is served with process while physically present in the forum State." Id. at 629 (Brennan, J., concurring in the judgment). Courts and scholars often refer to this basis for jurisdiction as "tag jurisdiction." See, e.g., In re Edelman, 295 F.3d 171, 179 (2002); Patrick J. Borchers, The Death of the Constitutional Law of Personal Jurisdiction: From Pennoyer to Burnham and Back Again, 24 U.C. DAvis L. REv. 19, 24 (1990) (recognizing Burnham as having validated tag jurisdiction for individuals).

50. Daimler, 134 S. Ct. at 764 (Sotomayor, J., concurring in the judgment).

51. Id. at 764 (Sotomayor, J., concurring in the judgment). Many cases involving huge corporations are, however, quite distinguishable from Goodyear and Daimler. See infra notes 134-36, 145-63 and accompanying text.

52. Int'l Shoe Co. v. Washington, 326 U.S. 310, 317-18 (1945) (focusing on quantity and quality of corporate contacts).

53. Goodyear and Daimler are only suggestive because neither addressed the case of extensive corporate forum contacts. See infra notes 145-63 and accompanying text. 
port general jurisdiction over individuals should mirror those the Court requires for corporations. ${ }^{54}$ General jurisdiction over individuals cannot soundly rest on the doctrinal underpinning that Goodyear and Daimler leave for it.

This Article proceeds in four parts. Part II briefly considers the constitutional law of personal jurisdiction over corporations from Pennoyer through International Shoe. Part III discusses the Goodyear and Daimler changes in the Court's approach to general jurisdiction over corporations. ${ }^{55}$ Part IV examines Goodyear's and Daimler's implications for International Shoe's jurisdictional theory. Part V explores the constitutional incongruence between standards of general jurisdiction over corporations and individuals.

\section{Dropping the Shoe: Corporate "Presence" Overtakes Minimum CONTACTS}

\section{A. Pennoyer Procrusteanism}

Pennoyer was the Court's first venture into personal jurisdiction. ${ }^{56}$ It prescribed four permissible bases: (1) consent, (2) residence, (3) service of process within the forum, and (4) property within the forum. ${ }^{57}$ The first three conferred in personam jurisdiction, the fourth conferred in rem or quasi in rem jurisdiction. ${ }^{58}$ Pennoyer's focus was exclusively territorial. ${ }^{59}$ That immediately presented problems with

54. That is not necessarily to say that Goodyear and Daimler are too narrow or that Burnham is too broad, only that there should not be such a gulf between them. This in turn requires reconsideration of International Shoe's theory of personal jurisdiction and the divergent readings of it that Justice Scalia and Justice Brennan expressed in Burnham. See supra note 16.

55. The Court elaborated International Shoe's minimum-contacts test many times after deciding International Shoe, but with the exceptions noted below, see infra notes 88-91 and accompanying text, all of those cases involved specific jurisdiction. "Since International Shoe, 'specific jurisdiction has become the centerpiece of modern jurisdiction theory, while general jurisdiction [has played] a reduced role.' . . . Our postInternational Shoe opinions on general jurisdiction, by comparison, are few." Daimler, 134 S. Ct. at 755.

56. See generally Pennoyer v. Neff, 95 U.S. 714, 733 (1877). "Personal jurisdiction" encompasses all forms of a court's entitlement to exercise power over the defendant or the defendant's interests, including as subdivisions in personam jurisdiction, in rem jurisdiction, and quasi in rem jurisdiction. See id. at 727.

57. Pennoyer, 95 U.S. at 723-26, 729 (The Court implied the residence basis for personal jurisdiction with its repeated references to "judgments rendered against nonresidents without personal service of process upon them.") (emphasis added). Inforum service replaced the much earlier English method of asserting personal jurisdiction: the capias ad respondendum, "[a] writ commanding the sheriff to take the defendant into custody to ensure that the defendant will appear in court." BLACK's LAW Dictionary 250 (10th ed. 2014); see also Pennoyer, 95 U.S. at 723-26.

58. Pennoyer, 95 U.S. at $725,729$.

59. See Pennoyer, 95 U.S. at 722: ("[E]very State possesses exclusive jurisdiction and sovereignty over persons and property within its territory ... [N]o State can exercise direct jurisdiction and authority over persons or property without its territory."). Consent to jurisdiction is an apparent contradiction to these principles, be- 
respect to non-consenting corporations. Where does a corporation "reside"? Often corporations received their charters from one state but did business only in another. ${ }^{60}$ For that matter, where is a corporation for purposes of making service? ${ }^{61}$ As Professor Stein has pointed out, the very nature of a corporation is that "the person of a corporation [ironically, considering the noun itself] is not embodied in any physical form comparable to an individual's body." 62 Corporations are incorporeal; they "have no feet." 63

Serving process on a corporation was complicated. Early courts ruled that one could effect service by delivering the summons to a corporate director or high-ranking officer. ${ }^{64}$ Some states also required corporations doing business within them to appoint a designated state official as an agent for service of process. ${ }^{65}$ The question

cause a defendant might enter a general appearance in an action without being in the forum. One suspects that the Court would have characterized this as the defendant being constructively within the forum.

60. That circumstance led to considerable difficulty in the area of diversity jurisdiction. The diversity jurisdiction statute, currently at 28 U.S.C. $\$ 1332$ (2012), originally provided that diversity jurisdiction existed when the suit was "between a citizen of the State where where the suit is brought, and a citizen of another State." Act of Sept. 29, 1789, ch. 20, § 11, 1 Stat. 73, 78 (1789) (current version at 28 U.S.C. $§ 1332$ (2012)). In 1958, Congress amended $\S 1332$ to provide that for purposes of diversity jurisdiction, a corporation was also a citizen of the state in which its "principal place of business" is located. Act of July 25, 1958, Publ. L. No. 85-554, 72 Stat. 415, 415 (1958) (codified as amended at 28 U.S.C. $§ 1332$ (c) (2012)). That, in turn, created the problem of how to define "principal place of business." Different federal courts developed different approaches, based either on where the corporate headquarters were (known as the "nerve center" test) or where the corporation carried on most of its "business activity." Hertz Corp. v. Friend, 559 U.S. 77, 91-92 (2010). The Supreme Court finally settled the question by adopting the nerve-center test. Id. at 78-79.

61. The Court had wrestled with related questions long before Pennoyer. Writing about diversity (subject matter), not personal, jurisdiction, Chief Justice Marshall's unanimous Court said that a corporation could not be a citizen of any state for diversity purposes. See Bank of the U.S. v. Deveaux, 9 U.S. (5 Cranch) 61, 86-87 (1809) (cited with approval in Hertz, Inc., 559 U.S. at 84 (2010)). Deveaux only allowed diversity jurisdiction involving corporations if "the corporation's shareholders were all citizens of a different State from the defendants. ..." Id. It took almost half a century after Deveaux for the Supreme Court to acknowledge that corporations had their own citizenship for diversity purposes. See Louisville, Cincinnati \& Charleston R.R. v. Letson, 43 U.S. (2 How.) 497, 558-59 (1844). Although the Court in both cases was speaking of subject-matter jurisdiction, its narrow view of the corporate entity nonetheless makes the cases relevant. In the area of personal jurisdiction, the concept of the corporate entity became enormously important.

62. Stein, supra note 48, at 534-35 (citing Philip B. Kurland, The Supreme Court, the Due Process Clause and the In Personam Jurisdiction of State Courts: From Pennoyer to Denckla, 25 U. CHI. L. REv. 569, 577 (1958)).

63. Id. at 534 .

64. See, e.g., Kansas City, Fort Scott \& Memphis R.R. v. Daughtry, 138 U.S. 298, 303-04 (1891) (following Tennessee statute calling for service on "president or other head of a corporation, or, in his absence, on the cashier, treasurer, or secretary, or, in the absence of such officers, on any director of such corporation"); see also JOSEPH H. Beale, Jr., 1 Treatise on the Conflict of Laws $\$ 87.2$, at 368 (1935).

65. See, e.g., N.Y. Bus. Corp. Law, § 304 (McKinney 2010); § 631, Ky. Stat. 1899 (Laws 1893, chap. 171, § 94); see generally BEALE, supra note 64, § 91.1, at 394-95. 
arose whether a state had jurisdiction over corporations under Pennoyer's presence-plus-service rationale simply because a director or officer received the summons within the state. Some states exercised jurisdiction on that basis. ${ }^{66}$ The Supreme Court disapproved unless the corporation was doing business in the state and the person receiving service was authorized to act in the state on corporate business. ${ }^{67}$ Corporate activity was the touchstone. ${ }^{68}$

Pennoyer's jurisdictional regime is notable both for its rigidity and for courts' creativeness in fitting cases within it. The Supreme Court held that a foreign corporation was amenable to forum jurisdiction if it carried on business in the forum:

[W]hen a corporation of one state goes into another, in order to be regarded as within the latter it must be there by its agents authorized to transact its business in that state. . . . It has been frequently held by this court, and it can no longer be doubted, that it is essential to the rendition of a personal judgment that the corporation be 'doing business' within the state. ${ }^{69}$

Tauza $a^{70}$ followed that approach, resting partly on the concept of "doing business within the state." 71 It explicitly linked such activity to one of the Pennoyer bases: service of process within the forum. ${ }^{72}$ To bring the case within that description, Judge Cardozo emphasized repeatedly that the activities that the corporate defendant's agents carried on within the forum rendered the corporation present in the forum. ${ }^{73}$ Referring to corporate presence, he used "here" eleven

\footnotetext{
In most of the American States a foreign corporation is now required before doing business in the State to appoint an agent for service of process upon it. The statute may require the selection of some real agent of the corporation, Id. or the acceptance of a state official for that purpose.

66. See, e.g., Hiller v. Burlington \& Mo. River R.R., 70 N.Y. 223 (1877).

67. See, e.g., Int'l Harvester Co. of Am. v. Kentucky, 234 U.S. 579, 583 (1914) ("The mere presence of an agent upon personal affairs does not carry the corporation into the foreign state."). Accord, Riverside \& Dan River Cotton Mills, Inc. v. Menefee, 237 U.S. 189 (1915); Goldey v. Morning News of New Haven, 156 U.S. 518, 52122; St. Clair v. Cox, 106 U.S. 350, 357 (1882).

68. Int'l Harvester, 234 U.S. at 583 (citing St. Louis Sw. Ry. Co. of Tex. v. Alexander, 227 U.S. 218, 226 (1913) ("[I]t is essential to the rendition of a personal judgment that the corporation be 'doing business' within the state.") (emphasis added); Riverside, 237 U.S. at 194-95 (referring to lack of jurisdiction where corporation "doing [no] business therein, or has done no business therein) (emphasis added). See also Goldey, 156 U.S. at 521-22 (noting ineffectiveness of service on corporate agent not in the forum on corporate business); St. Clair, 106 U.S. at 355, 357 (allowing jurisdiction over foreign corporation provided "the corporation be engaged in business in the state, and the agent [receiving service] be appointed to act there") (emphasis added). See generally BEALE, supra note 64, § 88.3, at 371-76.

69. Int'l Harvester, 234 U.S. at 583 (citing St. Louis Sw. Ry., 227 U. S. at 226 (collecting cases)).

70. See supra text accompanying notes $18-21$.

71. Tauza v. Susquehanna Coal Co., 115 N.E. 915 (N.Y. 1917).

72. Id. at 918.

73. See supra text accompanying note $18-19$.
} 
times in an opinion spanning little more than three pages; it is a veritable mantra. ${ }^{74}$

Other states also strained to fit cases into the Pennoyer framework. The non-resident-motorist statute was one of the best-known devices. The Court twice approved such statutes. Kane v. New Jersey upheld a statute that required non-resident drivers to execute and file a document appointing the secretary of state as the drivers' agent for service of process in cases arising from their in-state driving. ${ }^{75}$ If they failed to do so, they were subject to arrest and punishment. ${ }^{76}$ In Hess $v$. Pawloski, the Massachusetts statute provided that driving in the state constituted appointment of a state official as the driver's agent for service for claims arising out of driving in Massachusetts. ${ }^{77}$ A unanimous Court upheld the theory of the non-resident-motorist statute, reaffirming Pennoyer's territorial approach. ${ }^{78}$ Thus, the Massachusetts statute substituted implied appointment from the fact of driving in the state for New Jersey's explicit appointment, and the Court had no difficulty finding the difference insignificant for constitutional purposes. ${ }^{79}$ Kane's and Hess's importance for present purposes is their creative adherence to Pennoyer Procrusteanism.

74. The oxymoron of attributing physical presence to an incorporeal entity for purposes of service of process was consistent with the then-reigning theory of choiceof-law. In cases having connections with more than one state, the vested-rights approach to conflict of laws relied upon treating a multi-faceted transaction or event as if it happened entirely within one state, a process known as localization. See Larry Kramer, Return of the Renvoi, 66 N.Y.U. L. REV. 979, 992 (1991). Thus, the courts decided tort cases using the law of the state where the injury occurred even if, for example, the defendant's negligent act occurred in some other state. See, e.g., Ala. G. S. R.R. v. Carroll, 11 So. 803, 807 (Ala. 1892); Restatement (First) of Conflict of LAws $§ 377$ (1934) [hereinafter Restatement of Conflict]. Similarly, the law of the state where the parties contracted governed disputes arising out of the contract whether or not they arose in the same state. See Restatement of Conflict, supra, at $\$ \S 332-34$. Both the choice-of-law and jurisdictional approaches of the time have their roots in Pennoyer's exclusive reliance on territoriality. See supra note 1 and accompanying text.

75. Kane v. New Jersey, 242 U.S. 160, 166-67 (1916).

76. Id. at $164-65$.

77. Hess v. Pawloski, 274 U.S. 352, 356 (1927). For the text of the Massachusetts statute, see $i d$. at 354 .

78. "There must be actual service within the state of notice upon him or upon some one $[$ sic] authorized to accept service for him. A personal judgment rendered against a nonresident, who has neither been served with process nor appeared in the suit, is without validity." $I d$. at 355 (citations omitted).

79. Id. at $356-57$.

[I]n advance of the operation of a motor vehicle on its highway by a nonresident, the state may require him to appoint one of its officials as his agent on whom process may be served in proceedings growing out of such use. [Kane] recognized power of the state to exclude a nonresident until the formal appointment is made. And, having the power so to exclude, the state may declare that the use of the highway by the nonresident is the equivalent of the appointment of the registrar as agent on whom process may be served. The difference between the formal and implied appointment is not substan- 


\section{B. Breaking Pennoyer's Bonds}

International Shoe ameliorated the need to strain to fit within Pennoyer's four bases. ${ }^{80}$ The Court did not discard them, ${ }^{81}$ but it did adopt an entirely new approach to the due process analysis. ${ }^{82}$ Pennoyer rested exclusively on territoriality; International Shoe partially rejected it. ${ }^{83}$ It disapproved the fiction of corporate presence, relying heavily on Learned Hand's analysis. ${ }^{84}$ It expanded the reach of personal jurisdiction beyond the purely territorial and articulated a new constitutional test, recasting the personal jurisdiction inquiry in terms of "minimum contacts." Noting that jurisdiction originally rested only on presence, ${ }^{85}$ Chief Justice Stone observed:

tial, so far as concerns the application of the due process clause of the Fourteenth Amendment.

Id. (citations omitted). The Court did distinguish between cases involving individuals and those involving corporations. It noted that a state could not exclude individuals as it could corporations, and could not prevent individuals from transacting business.

Kane shows that although the state cannot exclude individuals, it can keep their vehicles out. Id.

80. Int'l Shoe Co. v. Washington, 326 U.S. 310, 316-18 (1945).

81. Shaffer v. Heitner, 433 U.S. 186, 196 (1977), while not eliminating quasi in rem jurisdiction, significantly restricted it by ruling that property in the forum unrelated to the parties' dispute, without more, was insufficient to satisfy International Shoe's dueprocess approach. $I d$. at 196-98.

82. Int'l Shoe, 326 U.S. at 316-18.

83. Id. at 316.

Since the corporate personality is a fiction, although a fiction intended to be acted upon as though it were a fact, . . . it is clear that unlike an individual its "presence" without, as well as within, the state of its origin can be manifested only by activities carried on in its behalf by those who are authorized to act for it. To say that the corporation is so far "present" there as to satisfy due process requirements, for purposes of taxation or the maintenance of suits against it in the courts of the state, is to beg the question to be decided. For the terms "present" or "presence" are used merely to symbolize those activities of the corporation's agent within the state which courts will deem to be sufficient to satisfy the demands of due process.

Id. (citation omitted).

84. See supra notes 24-27 and accompanying text.

85. "Historically the jurisdiction of courts to render judgment in personam is grounded on their de facto power over the defendant's person. Hence his presence within the territorial jurisdiction of court was prerequisite to its rendition of a judgment personally binding him." Int'l Shoe, 326 U.S. at 316. See also Stein, supra note 48, at 534 ("The sole measure of constitutional legitimacy in Pennoyer was the physical presence of the person or property of the defendant in the forum at the time that jurisdiction was asserted.").

Professor Hazard has criticized this view and Pennoyer's entirely territorial approach to personal jurisdiction. See Geoffrey C. Hazard, Jr., A General Theory of State-Court Jurisdiction, 1965 Sup. CT. Rev. 241, 252-72. In Burnham v. Superior Court, 495 U.S. 604, 611 (1990) (Scalia, J., concurring in the opinion), Justice Scalia rejoined, after noting Professor Hazard's reservations (and also citing Albert A. Ehrenzweig, The Transient Rule of Personal Jurisdiction: The "Power" Myth and Forum Conveniens, 65 YALE L.J. 289 (1956)), "Accurate or not, however, judging by the evidence of contemporaneous or near-contemporaneous decisions, one must conclude that ... understanding was shared by American courts at the crucial time for present 
But now that the capias ad respondendum has given way to personal service of summons or other form of notice, due process requires only that in order to subject a defendant to a judgment in personam, if he be not present within the territory of the forum, he have certain minimum contacts with it such that the maintenance of the suit does not offend "traditional notions of fair play and substantial justice." 86

State and federal courts, legal scholars, and countless lawyers and law students have been trying to attribute somewhat predictable meaning to "minimum contacts" and "traditional notions" ever since.

\section{General Jurisdiction Over Corporations}

Every student of Civil Procedure knows the cases that command primary attention: International Shoe Co. v. Washington, ${ }^{87}$ Perkins v. Benguet Consolidated Mining Co., ${ }^{88}$ Helicopteros Nacionales de Colombia S.A. v. Hall, ${ }^{89}$ Goodyear, ${ }^{90}$ and now, Daimler. ${ }^{91}$ Although International Shoe was not a general jurisdiction case, it articulated the jurisdictional analysis that the Court faithfully used-until Goodyear and Daimler. In dictum, it cautiously recognized general jurisdiction over corporations: "[T]here have been instances in which the continuous corporate operations within a state were thought so substantial and of such a nature as to justify suit against it on causes of action arising from dealings entirely distinct from those activities." 92

purposes: 1868, when the Fourteenth Amendment was adopted." Accord, IV Wright \& Miller, supra note 48, § 1064, at 335-36 (2002).

86. Int'l Shoe, 326 U.S. at 316 (quoting Milliken v. Meyer, 311 U.S. 457, 463 (1940)). Thus, this most famous phrase from International Shoe-"certain minimum contacts ... such that the maintenance of the suit does not offend "traditional notions of fair play and substantial justice" "- suggests recognizing what one might call "presence proxies." See infra notes 244-68 and accompanying text.

87. See generally Int'l Shoe, 326 U.S. 310. International Shoe was not a general jurisdiction case; the state's claim against the corporation arose exclusively from actions by corporate agents within Washington. That caused the Court to note that amenability to jurisdiction "has never been doubted when the activities of the corporation there have not only been continuous and systematic, but also give rise to the liabilities sued on. ..." Id. at 317.

88. Perkins v. Benguet Consol. Mining Co., 342 U.S. 437 (1952).

89. Helicopteros Nacionales de Colom., S.A. v. Hall, 466 U.S. 408 (1984).

90. Goodyear Dunlop Tires Operations, S.A. v. Brown, 131 S. Ct. 2846 (2011).

91. Daimler AG v. Bauman, 134 S. Ct. 746 (2014). As the Goodyear Court noted, "Since International Shoe, this Court's decisions have elaborated primarily on circumstances that warrant exercise of specific jurisdiction, particularly in cases involving 'single or occasional acts' occurring or having their impact within the forum State." Goodyear, 131 S. Ct. at 2854.

92. Int'l Shoe, 326 U.S. at 318 (citing Mo., Kan. \& Tex. Ry. Co. v. Reynolds, 255 U.S. 565 (1921) and Tauza v. Susquehanna Coal Co., 115 N.E. 915 (N.Y. 1917)). See supra notes 19-23, 32-36, and accompanying text. The caution came a page earlier:

[I]t has been generally recognized that the casual presence of the corporate agent or even his conduct of single or isolated items of activities in a state in the corporation's behalf are not enough to subject it to suit on causes of action unconnected with the activities there. To require the corporation in 
Of its four general jurisdiction cases involving corporate defendants, the Court has only upheld jurisdiction in Perkins. During World War II, the defendant, a Philippine mining corporation, suspended operations because of the Japanese occupation..$^{33}$ There is no indication in the opinion that the company had mining operations anywhere other than the Philippines. ${ }^{94}$ During the occupation, the company president, who was also the general manager and principal stockholder, conducted the corporation's few business affairs from his Ohio home. ${ }^{95}$ As the Court summarized those activities: "Thus he carried on in Ohio a continuous and systematic supervision of the necessarily limited wartime activities of the company." 96 Although the corporation's forum activities were not as extensive as those of many large corporations today, the Court allowed Ohio to assert personal jurisdiction. ${ }^{97}$

In Helicopteros, the Court refused to allow Texas to exercise general jurisdiction over a Colombian corporation that had a continuous (but limited) course of contact with Texas. ${ }^{98}$ The defendant's commercial helicopter business operated entirely in South America. ${ }^{99}$ As the Court described the activities, they sounded at least as voluminous

such circumstances to defend the suit away from its home or other jurisdiction where it carries on more substantial activities has been thought to lay too great and unreasonable a burden on the corporation to comport with due process.

Int'l Shoe, 326 U.S. at 317 (citations omitted).

93. Perkins, 342 U.S. at 447.

94. $I d$. at 448 .

95. Id. at 447-48.

There he maintained an office in which he conducted his personal affairs and did many things on behalf of the company. He kept there office files of the company. He carried on there correspondence relating to the business of the company and to its employees. He drew and distributed there salary checks on behalf of the company, both in his own favor as president and in favor of two company secretaries who worked there with him. He used and maintained in Clermont County, Ohio, two active bank accounts carrying substantial balances of company funds. A bank in Hamilton County, Ohio, acted as transfer agent for the stock of the company. Several directors' meetings were held at his office or home in Clermont County. From that office he supervised policies dealing with the rehabilitation of the corporation's properties in the Philippines and he dispatched funds to cover purchases of machinery for such rehabilitation. ... He there discharged his duties as president and general manager, both during the occupation of the company's properties by the Japanese and immediately thereafter. While no mining properties in Ohio were owned or operated by the company, many of its wartime activities were directed from Ohio and were being given the personal attention of its president in that State at the time he was served with summons.

Id.

96. $I d$. at 447 (emphasis added).

97. $I d$. at 448 .

98. Helicopteros Nacionales de Colombia S.A. v. Hall, 466 U.S. 408, 418-19 (1984).

99. Id. at 409 . 
as those of Benguet in Perkins. ${ }^{100}$ There were a few differences, however: Benguet conducted directors' meetings at its president's Ohio home and had an Ohio bank act as a stock transfer agent. ${ }^{101}$ To the extent that Benguet had a principal place of business during the Japa-

100. Id. at 410-11.

At the time of the crash, respondents' decedents were employed by Consorcio, a Peruvian consortium, and were working on a pipeline in Peru. Consorcio is the alter ego of a joint venture named Williams-Sedco-Horn (WSH). The venture had its headquarters in Houston, Tex. Consorcio had been formed to enable the venturers to enter into a contract with Petro Peru, the Peruvian state-owned oil company. Consorcio was to construct a pipeline for Petro Peru running from the interior of Peru westward to the Pacific Ocean. Peruvian law forbade construction of the pipeline by any non-Peruvian entity. The participants in the joint venture were Williams International Sudamericana, Ltd., a Delaware corporation; Sedco Construction Corporation, a Texas corporation; and Horn International, Inc., a Texas corporation. Consorcio/WSH needed helicopters to move personnel, materials, and equipment into and out of the construction area. In 1974, upon request of Consorcio/WSH, the chief executive officer of Helicol, Francisco Restrepo, flew to the United States and conferred in Houston with representatives of the three joint venturers. At that meeting, there was a discussion of prices, availability, working conditions, fuel, supplies, and housing. Restrepo represented that Helicol could have the first helicopter on the job in 15 days. The Consorcio/WSH representatives decided to accept the contract proposed by Restrepo. Helicol began performing before the agreement was formally signed in Peru on November 11, 1974. The contract was written in Spanish on official government stationery and provided that the residence of all the parties would be Lima, Peru. It further stated that controversies arising out of the contract would be submitted to the jurisdiction of Peruvian courts. In addition, it provided that Consorcio/WSH would make payments to Helicol's account with the Bank of America in New York City.

Aside from the negotiation session in Houston between Restrepo and the representatives of Consorcio/WSH, Helicol had other contacts with Texas. During the years 1970-1977, it purchased helicopters (approximately $80 \%$ of its fleet), spare parts, and accessories for more than $\$ 4$ million from Bell Helicopter Company in Fort Worth. In that period, Helicol sent prospective pilots to Fort Worth for training and to ferry the aircraft to South America. It also sent management and maintenance personnel to visit Bell Helicopter in Fort Worth during the same period in order to receive "plant familiarization" and for technical consultation. Helicol received into its New York City and Panama City, Fla., bank accounts over $\$ 5$ million in payments from Consorcio/WSH drawn upon First City National Bank of Houston. Beyond the foregoing, there have been no other business contacts between Helicol and the State of Texas. Helicol never has been authorized to do business in Texas and never has had an agent for the service of process within the State. It never has performed helicopter operations in Texas or sold any product that reached Texas, never solicited business in Texas, never signed any contract in Texas, never had any employee based there, and never recruited an employee in Texas. In addition, Helicol never has owned real or personal property in Texas and never has maintained an office or establishment there. Helicol has maintained no records in Texas and has no shareholders in that State.

Id. (footnotes omitted).

101. Perkins, 342 U.S. at 448. 
nese occupation, it clearly was Ohio, although the Perkins Court did not use that diversity-derived term in its opinion. ${ }^{102}$

It is not astonishing that the Helicopteros Court declined to allow the exercise of general jurisdiction. On the other hand, Perkins described Benguet's Ohio activities as "a continuous and systematic, but limited, part of its general business," 103 and the Texas activities of the Colombian corporation in Helicopteros come within that shorthand description. But the Court, relying on a case antedating International Shoe by two decades, ${ }^{104}$ concluded that Helicopteros was not subject to general jurisdiction. ${ }^{105}$ The Court mentioned Perkins, but it never distinguished it, for which Justice Brennan took the majority to task. ${ }^{106}$ Most important for present purposes is that neither Perkins nor Helicopteros discussed the relationship of the foreign corporation's forum business with its total business activities. The Court did not invent that comparison until Daimler. ${ }^{107}$

\section{A. Enter Goodyear}

The accident underlying the Goodyear tort claim happened near Paris, France, allegedly because of a defectively manufactured tire. ${ }^{108}$ North Carolina attempted to exercise general jurisdiction over three of Goodyear USA's European subsidiaries. ${ }^{109}$ The sudsidiaries' con-

102. Id. at 447-48. There is no indication in the facts that any aspect of Helicopteros' corporate governance occurred in Texas, a clear distinction from Perkins. Helicopteros did not use "principal place of business" either; that term did not appear in conjunction with personal jurisdiction until Goodyear. See id.

103. Perkins, 342 U.S. at 438 (emphasis added).

104. See Rosenberg Bros. \& Co. v. Curtis Brown Co., 260 U.S. 516, 518 (1923) (holding in-state purchases and other related trips insufficient to support inference of presence and, hence, general jurisdiction).

105. Helicopteros, 466 U.S. at 418.

106. See id. at 420-24 (Brennan, J., dissenting). Professor Brilmayer and her colleagues offered a distinction. Lea Brilmayer et al., A General Look at General Jurisdiction, 66 Tex. L. Rev. 721, 744 (1988).

A defendant's intrastate activity should count more heavily towards general jurisdiction than its purely interstate activity-that in-state activity which engages the defendant from across the state's borders. An example of interstate activity would be the solicitation of orders from out of state, whereas intrastate activity would include local manufacturing or management. This distinction helps to explain the different results of Helicopteros and Perkins. In Perkins, the Court permitted Ohio to exercise general jurisdiction over a Philippine corporation whose forum contacts consisted of directors' meetings, business correspondence, banking, stock transfers, payment of salaries, and the general management of the corporation's wartime activities by its Ohio-based president. Unlike those in Perkins, the contacts in Helicopteros were not primarily the result of intrastate transactions.

Id. (footnotes omitted).

107. See infra notes $131-36$ and accompanying text.

108. Goodyear Dunlop Tires Operations, S.A. v. Brown, 131 S. Ct. 2846, 2851 (2011).

109. Id. at 2851-52. 
tacts with North Carolina were quite limited and indirect. ${ }^{110}$ The parent company conceded, however, that its own contacts were sufficient to support general jurisdiction. ${ }^{111}$ The unanimous Court said the subsidiaries' contacts were insufficient, noting that the subsidiaries made no effort to serve the North Carolina market. ${ }^{112}$ It created the essentially-at-home test for exercising general jurisdiction over corporations and cited International Shoe. ${ }^{113}$ But International Shoe did not say "essentially at home"; it could neither have said nor intended that gloss on general jurisdiction while simultaneously have approving Tauza's result. ${ }^{114}$ Susquehanna Coal clearly was not "essentially at home" in New York, and Judge Cardozo did not pretend otherwise. He rested instead on corporate presence, a concept that International Shoe rejected even while approving Tauza's result. ${ }^{115}$ By creating the essentially-at-home standard, Goodyear outlawed general jurisdiction over corporations that International Shoe would have permitted. ${ }^{116}$

The Goodyear Court distinguished Perkins and aptly used Helicopteros to demonstrate how much weaker the contacts in Good-

110. As the Court described:

$[P]$ titioners are not registered to do business in North Carolina. They have no place of business, employees, or bank accounts in North Carolina. They do not design, manufacture, or advertise their products in North Carolina. And they do not solicit business in North Carolina or themselves sell or ship tires to North Carolina customers. Even so, a small percentage of petitioners' tires (tens of thousands out of tens of millions manufactured between 2004 and 2007) were distributed within North Carolina by other Goodyear USA affiliates.... Petitioners state, and respondents do not here deny, that the type of tire involved in the accident, ... manufactured by Goodyear Turkey, was never distributed in North Carolina. Id. at 2852 .

111. The Court's decision, however, casts doubt on whether Goodyear USA should have made that concession. Id. at 2857. See also supra text accompanying note 42.

112. See Goodyear, 131 S. Ct. at 2851. The Court also discussed at length the error it found in the North Carolina courts' analysis: confusing the criteria for specific jurisdiction with those for general jurisdiction. See id. at 2854-56. That discussion is not relevant to this article.

113. Id. at 2853-54. Professor Andrews views Goodyear as merely clarifying International Shoe's general-jurisdiction standard. With all respect, I see it differently. See Andrew, supra note 42 and accompanying text. See also Andrew, supra note 27.

114. The Tauza Court, hemmed in by the four bases for personal jurisdiction that Pennoyer had articulated forty years earlier, relied on the corporation's activities in New York for the conclusion that it was present in the state. See generally Tauza v. Susquehanna Coal Co., 115 N.E. 915 (N.Y. 1917). See supra notes 19-23 and accompanying text. International Shoe rejected what it viewed as the fiction of corporate presence in favor of the minimum-contacts approach. See generally Int'l Shoe Co. v. Washington, 326 U.S. 310 (1945). See supra notes 22-25 and accompanying text.

115. Tauza, 115 N.E. at 918.

116. Justice Ginsburg's opinion sought support for the new rule in the International Shoe opinion. "A corporation's 'continuous activity of some sorts with a state,' International Shoe instructed, 'is not enough to support the demand that the corporation be amenable to suits unrelated to that activity." Goodyear, $131 \mathrm{~S}$. Ct. at 2856. That is true, of course, but severed from the International Shoe Court's simultaneous approving the Tauza result and citation of Missouri, Kansas, it is misleading. 
year were. ${ }^{117}$ Helicopteros had direct contacts with the forum in three respects: (1) Its president negotiated part of the contract in the forum; (2) the defendant's pilots went to the forum for training, and (3) the defendant had made multiple helicopter purchases from a forum company. ${ }^{118}$ If those contacts were not enough to support general jurisdiction, it is difficult to imagine how Goodyear's European subsidiaries' much more limited and indirect contacts with North Carolina could suffice. Accordingly, Goodyear should have been an easy case. There was no need to announce a new approach to general jurisdiction over corporations. Helicopteros had not, and Goodyear's facts were clearer yet. ${ }^{119}$

\section{B. Daimler}

Daimler also involved a foreign claim, this time arising in Argentina. ${ }^{120}$ The plaintiffs alleged that the German parent company Daimler had "collaborated with state security forces to kidnap, detain, torture, and kill" plaintiffs' decedents, employees of Daimler's Argentina subsidiary. ${ }^{121}$ Plaintiffs sued the parent in California, though none of the acts alleged had anything to do with California. ${ }^{122}$ Daimler moved to dismiss for lack of personal jurisdiction. ${ }^{123}$ The plaintiff sought to attribute Daimler's United States subsidiary's ("MBUSA") California contacts to the German parent. ${ }^{124}$ Daimler resisted, relying in large part on Goodyear. ${ }^{125}$ The subsidiary's contacts with California were considerable. Its California sales amounted to $2.4 \%$ of Daimler's global sales, which were $\$ 192$ billion annually. ${ }^{126}$ Thus, the subsidiary's California sales that year exceeded $\$ 4.6$ billion.

117. Id. at $2856-57$.

118. Id. at 2857.

119. The plaintiffs were not quite finished trying, however. They asserted what the Court called a "'single enterprise' theory," seeking to attribute the parent company's North Carolina contacts to the European subsidiaries. Id. at 2857. The Court rejected the effort. "In effect, respondents would have us pierce Goodyear corporate veils, at least for jurisdictional purposes." Id. The Court refused even to consider the argument, noting that the plaintiffs had never raised the point either in the North Carolina courts or in their brief in opposition to certiorari (holding that "[r]espondents have therefore forfeited this contention, and we do not address it.") Id.

120. Daimler AG v. Bauman, 134 S. Ct. 746, 750-51 (2014).

121. Id. at 751 .

122. Id. at 750 .

123. Id. at 752. The district court found the parent's contacts with California insufficient to support general jurisdiction, but the Ninth Circuit reversed. Id. at 753.

124. Id. at 752. The subsidiary was a Delaware corporation with its principal place of business in New Jersey. Id. In one way, the case is the reverse of Goodyear. There, the plaintiffs sought to attribute the parent's North Carolina contacts to the European subsidiaries. Goodyear, $131 \mathrm{~S}$. Ct. at 2852.

125. Daimler, 134 S. Ct. at 751.

126. Id. at 752 . 
The Court, unanimous on the result though not on the theory, ${ }^{127}$ denied jurisdiction. ${ }^{128}$ Though observing that some subsidiaries might be agents for their parents in some circumstances, the Court disapproved the Ninth Circuit's approach. ${ }^{129}$ "The Ninth Circuit's agency theory . . . appears to subject foreign corporations to general jurisdiction whenever they have an in-state subsidiary or affiliate, an outcome that would sweep beyond even the 'sprawling view of general jurisdiction' we rejected in Goodyear." 130 To that point, the opinion was unexceptional.

The Court then introduced "relative contacts" in personal jurisdiction. Referring to Goodyear's essentially-at-home formulation, the Court observed:

Even if we were to assume that MBUSA is at home in California, and further to assume MBUSA's contacts are imputable to Daimler, there would still be no basis to subject Daimler to general jurisdiction in California, for Daimler's slim contacts with the State hardly render it at home there. ${ }^{131}$

One may wonder how, if MBUSA's contacts are sufficient to establish at-home status, they suddenly become insufficient if attributed to the parent. ${ }^{132}$ The Court explained in a footnote:

[T]he general jurisdiction inquiry does not "focu[s] solely on the magnitude of the defendant's in-state contacts." General jurisdiction instead calls for an appraisal of a corporation's activities in their entirety, nationwide and worldwide. A corporation that operates in many places can scarcely be deemed at home in all of them. Otherwise, "at home" would be synonymous with "doing business" tests framed before specific jurisdiction evolved in the United States. Nothing in International Shoe and its progeny suggests that

127. Justice Sotomayor concurred in the judgment only and filed an opinion disputing the majority's analysis and setting out her own. See id. at 763 (Sotomayor, J., concurring in the judgment).

128. Id. at 761-62.

129. Id. at 759 .

130. Id. at 759-60 (quoting Goodyear Dunlop Tires Operations, S.A. v. Brown, 131 S. Ct. 2846, 2856 (2011)). Justice Ginsburg observed that the plaintiffs had declined to rely on the Ninth Circuit's agency analysis, and she noted that agency is far more useful with respect to specific jurisdiction. See id. at 759 nn.13-14.

131. Id. at 760 (footnote omitted). The Court was a bit misleading here. MBUSA's forum contacts, sufficient for general jurisdiction by the Court's assumption, augmented "Daimler's slim contacts." See id. The Court avoided the inferential result by introducing relative contacts. Scholars writing before Daimler criticized that approach: "Significantly, for purposes of general jurisdiction, the relevant issue is the absolute amount of activity, not the amount of activity relative to what the defendant does outside the state." Brilmayer, supra note 106, at 743 (emphasis added).

132. Justice Sotomayor castigated the majority for its approach. "Had the majority applied our settled approach, it would have had little trouble concluding that Daimler's California contacts rise to the requisite level, given the majority's assumption that MBUSA's contacts may be attributed to Daimler and given Daimler's concession that those contacts render MBUSA 'at home' in California." Daimler, 134 S. Ct. at 769 (Sotomayor, J., concurring in the judgment). 
"a particular quantum of local activity" should give a State authority over a "far larger quantum of . . . activity" having no connection to any in-state activity. ${ }^{133}$

Thus, neither the absolute volume of a corporation's forum contacts nor the continuous nature of those contacts that will support general jurisdiction in the future. Some calculus (known only to the Court) considers the corporation's forum business in comparison with its total business. A Delaware corporation that does all of its business in Kansas is subject to general jurisdiction there even if its annual business amounts only to $\$ 50,000$ and it has only one employee. Whereas a corporation like General Motors, which has 3,900 Kansas employees, operates a large manufacturing site that produces a new vehicle every fifty-eight seconds, and has been in operation since $1987,{ }^{134}$ may not be. ${ }^{135}$ Perhaps that is the structure the Court

133. Id. at 762 n.20. One might apply the final sentence to transient jurisdiction as well. See id. Does anything "in International Shoe and its progeny," including Goodyear, suggest that an individual's temporary presence in a state should give the state authority to adjudicate anything related to the individual's entire life? See infra text accompanying note 275 . Perhaps it is equally important that nothing in International Shoe or its progeny suggests the reverse, either. Note also that some courts have exercised general jurisdiction over individuals based on their doing business in the forum in situations in which it is clear that they are not "essentially at home." See, e.g., Harrelson v. Seung Heun Lee, 798 F. Supp. 2d 310, 316-17 (D. Mass. 2011); ABKCO Indus., Inc. v. Lennon, 384 N.Y.S.2d 781, 783-84 (N.Y. App. Div. 1976).

134. See GM Fairfax, Kansas Plant Info, GM AuTH., http://gmauthority.com/blog/ gm/gm-manufacturing/gm-fairfax-assembly/ (last visited Oct. 7, 2014).

135. I infer this from Daimler on the following basis. If GM manufactures one vehicle every fifty-eight seconds for a year, never closing the facility, the Kansas plant, which builds the Buick LaCrosse and Chevrolet Malibu, produces 543,724 cars that year. The Malibu that GM pictures on its site has a manufacturer's suggested retail price of \$25,410. See 2014 Malibu. Model Overview, Chevrolet, http://chevrolet .com/2014-malibu-mid-size-sedan.html (last visited Oct. 7, 2014). GM lists the most expensive trim model of the Buick LaCrosse at $\$ 39,755$. See Request a Quote, Buick, http://buick.com/request-quote.hmtl (select "2014"; "LaCrosse"; "FWD"; "LaCrosse Premium II Group") (last visited Oct. 7, 2014). Assuming that GM manufactures only that model Buick for an entire year, the Kansas plant would produce approximately $\$ 21.6$ billion annual revenue. The 2013 GM Annual Report shows annual revenue of $\$ 155$ billion. See General Motors Company 2013 Annual Report, http://www .gm.com/content/dam/gmcom/COMPANY/Investors/Stockholder_Information/PDFs/ 2013_GM_Annual_Report.pdf (last visited Oct. 7, 2014). Thus, even the "best case scenario" for the Kansas plant that I have posited, it accounts for only a bit under $14 \%$ of GM's revenue. Under Daimler's relative-contacts approach, is GM "essentially at home" in Kansas? Perhaps it is; in percentage terms, it has roughly 5.4 times as much Kansas income as Daimler had California income. On the other hand, Kansas accounts for less than one-fifth of GM's annual revenue on the figures used. If one assumes the $\$ 32,582.50$ average price of the high-end Buick and the Chevrolet Malibu (probably a more realistic figure), the percentage drops to just over $11.5 \%$. If an individual spent a comparable amount of a year (about 42 days) in a state which was not his domicile, would the Court characterize the individual as essentially at home there? 
wants, but it is difficult to explain it in terms of "minimum contacts." 136

One must note what Goodyear and Daimler did not say. Both spoke of corporations being "essentially at home," prompting thoughts of corporations' states of incorporation and principal places of business - the points of reference for diversity jurisdiction with corporations as parties. ${ }^{137}$ It would have been easy for the Court to say that general jurisdiction was available only in those places, but neither case said that. Daimler was explicit: "Goodyear did not hold that a corporation may be subject to general jurisdiction only in a forum where it is incorporated or has its principal place of business; it simply typed those places paradigm all-purpose forums."138 Both cases cited Perkins with approval, as an example (the only one at the Supreme Court level) of proper exercise of general jurisdiction. ${ }^{139}$ Neither characterized Perkins as a case limited to its peculiar facts.

Daimler even acknowledged International Shoe's recognition of general jurisdiction, quoting Chief Justice Stone's language. ${ }^{140}$ It then quoted Goodyear's essentially-at-home limitation of Stone's language. ${ }^{141}$ Goodyear did not comment on the fact that International Shoe made no mention of general jurisdiction over corporations being limited to their "homes"; the International Shoe Court used that term elsewhere in the opinion ${ }^{142}$ and had a clear chance to limit general jurisdiction to those two places, yet it did not. In fact, the language it subsequently used to describe general jurisdiction (and that Daimler

136. The Daimler Court criticized plaintiffs' reliance on "'substantial, continuous, and systematic course of business," Daimler, 134 S. Ct. at 761 (quoting plaintiffs' brief declaring "[t]hat formulation . . . is unacceptably grasping."). Ironically, the unanimous Goodyear Court had used "continuing and systematic" as a measure of sufficient corporate activity. Goodyear, $131 \mathrm{~S}$. Ct. at 2851. But the plaintiffs had reason to rely on that verbal formulation of "continuing and systematic" contact because both, Perkins and Helicopteros, had referred to "continuous and systematic" contacts. Helicopteros Nacionales de Colom., S.A. v. Hall, 466 U.S. 408, 416 (1984); Perkins v. Benguet Consolidated Mining Co., 342 U.S. 437, 438 (1952). In arguing that International Shoe did not stand for the proposition that continuous and systematic business contacts could give rise to general jurisdiction, the Court ignored those two cases and the many lower court cases that used essentially the same vocabulary. See supra note 28.

137. See 28 U.S.C. $\S 1332$ (c) (2012).

138. Daimler, $134 \mathrm{~S}$. Ct. at 760 . The Court's apparent unwillingness simply to adopt the diversity reference points cannot have been inadvertent; Justice Ginsburg was, after all, a Civil Procedure professor. Sonia Sotomayor \& Linda Greenhouse, A Conversation with Justice Sotomayor, 123 YALE L.J. Forum 375, 386 (2014).

139. Goodyear Dunlop Tires Operations, S.A. v. Brown, 131 S. Ct. 2846, 2857 (2011); Daimler, 134 S. Ct. at 755-56.

140. Daimler, 134 S. Ct. at 755 (quoting Int'l Shoe Co. v. Washington, 326 U.S. 310 , 318 (1945)).

141. $I d$.

142. See Int'l Shoe, 326 U.S. at 317 (referring to " 'the inconveniences' which would result to the corporation from a trial away from its 'home' or principal place of business ....".). 
quoted) connotes that the Court did not intend such a limitation: "[T]here have been instances in which the continuous corporate operations within a state were thought so substantial and of such a nature as to justify suit against it on causes of action arising from dealings entirely distinct from those activities." 143 That language from International Shoe, only one page after the reference to the corporation's diversity citizenships, is inconsistent with the interpretation that Goodyear and Daimler later placed on it. ${ }^{144}$

\section{General Jurisdiction Over Corporations: The Empty Record}

Perhaps the most striking thing about general jurisdiction over corporations in the Supreme Court is how few times the Court has addressed it since International Shoe. There are only four cases, ${ }^{145}$ and not one deserves to be called close. ${ }^{146}$ All involved non-U.S. corporations. In Perkins, the action began after the corporation had moved its corporate headquarters to the forum because of the Japanese occupation of the Philippines. ${ }^{147}$ In diversity terms, the forum was its principal place of business. ${ }^{148}$ In Goodyear-Daimler terms, it was "home." 149

The other three cases are notable for the dearth of contacts between the alien corporate defendant and the forum. Helicopteros did not operate in Texas; its only contacts with the forum were the partial negotiation of the contract, purchasing equipment (including helicopters) from a Texas manufacturer, and sending employees there for training. ${ }^{150}$ The case sounded in tort, not contract, and the plaintiffs

143. Id. at 318 (emphasis added).

144. Professor Pielemeier regards Goodyear's approach as "shifting the focus slightly ...." Pielemeier, supra note 28, at 971. I see it as a substantial shift in approach.

145. See Daimler, 134 S. Ct. at 746; Goodyear Dunlop Tires Operations, S.A. v. Brown, 131 S. Ct. 2846 (2011); Helicopteros Nacionales de Colom., S.A. v. Hall, 466 U.S. 408 (1984); Perkins v. Benguet Consol. Mining Co., 342 U.S. 437 (1952).

146. Professor Twitchell has noted the "impoverished body of general jurisdiction case law that fails to explore the question of the state's general adjudicatory over nonresident defendants. ..." Mary Twitchell, The Myth of General Jurisdiction, 101 HARV. L. Rev. 610, 612 (1988).

147. Perkins, 342 U.S. at 448.

148. See Hertz Corp. v. Friend, 559 U.S. 77, 91-92 (2010).

149. See supra note 48 and accompanying text.

150. See supra note 100. The Court also noted that Helicopteros had deposited checks from the Peruvian consortium, "the alter ego of a joint venture ..." with its headquarters in Texas. Helicopteros, 466 U.S. at 410. Why the location of the bank on which a non-defendant's checks were drawn to make payments on a contract not the subject of the action should count as a forum contact for the defendant remains a mystery. But see McGee v. Int'l Life Ins. Co., 355 U.S. 220, 222-23 (1957) (noting twice in the jurisdictional discussion that the defendant company had received premium checks from the forum). McGee is easily distinguishable, however. There the action was on the underlying insurance contract, and throughout the insurance period, the defendant had dealt with the insured in the forum. Neither was the case in Helicopteros. 
were not parties to the contract between Helicopteros and Bell Helicopter, the Texas manufacturer. ${ }^{151}$ The Court recited the paucity of the defendant's forum contacts. ${ }^{152}$ In the language of International Shoe, the defendant had no "continuous corporate operations within [Texas] ... so substantial and of such a nature as to justify suit against it on causes of action arising from dealings entirely distinct from those activities." 153 Even Justice Brennan, alone in dissent, acknowledged that "the Court's holding on this issue is neither implausible nor unexpected." 154 Helicopteros was an easy case.

Goodyear and Daimler were, if anything, easier, which may help explain why the Court was unanimous on the result in both cases and unanimous on the reasoning in one. ${ }^{155}$ Both involved parent corporations and subsidiaries. In Goodyear, the parent was a United States corporation and the European subsidiaries objected to jurisdiction. ${ }^{156}$ The plaintiffs wanted to attribute the parent's forum contacts to the subsidiaries, but the Court refused. ${ }^{157}$ Daimler presented the reverse situation: a European parent with a United States subsidiary, the forum contacts of which the plaintiffs wanted to attribute to the parent. ${ }^{158}$ The Court refused again. ${ }^{159}$ In both cases, the European defendants had attenuated forum contacts, and no one suggested those contacts alone were sufficient to support general jurisdiction.

The Court has yet to confront a case between the extremes that Perkins on one hand and Helicopteros, Goodyear, and Daimler on the other represent, and those cases tell little about the great expanse that lies between. Suppose a corporation carries on extensive operations in a state that is neither its state of incorporation nor its principal place of business. Suppose further, to track the language from Helicopteros ${ }^{160}$ that the corporation sells its product and performs

151. Helicopteros, 466 U.S. at 409-13.

152. Id. at 411.

153. Int'l Shoe Co. v. Washington, 326 U.S. 310, 318 (1945).

154. Helicopteros, 466 U.S. at 419 (Brennan, J., dissenting). Justice Brennan would have considered the case under specific jurisdiction, but "[a]ll parties . . . concede[d] that respondents' claims against Helicol did not 'arise out of,' and [were] not related to, Helicol's activities within Texas." Id. at 415.

155. Justice Sotomayor concurred in the Daimler judgment but thought that the majority opinion was too broad and introduced a new way of approaching general jurisdiction cases that was unnecessary to the disposition of the case. See supra notes 131-133 and accompanying text. In a comment after the decision, Justice Sotomayor noted: "The Court announced a rule limiting the test for general jurisdiction on a set of facts that were the worst for the exercise of jurisdiction." Sotomayor \& Greenhouse, supra note 138, at 386.

156. Goodyear Dunlop Tires Operations, S.A. v. Brown, 131 S. Ct. 2846, 2850 (2011).

157. Id. at 2857. The refusal rested on the plaintiffs' failure to raise and preserve the attribution argument in the lower courts or in their brief opposing certiorari.

158. Daimler AG v. Bauman, 134 S. Ct. 746, 752 (2014).

159. Id. at 759-60.

160. See Helicopteros Nacionales de Colom, S.A. v. Hall, 466 U.S. 408 (1984). 
consumer services, solicits business, signs contracts, has thousands of employees, recruits new employees, owns vast tracts of land used for producing its products and services, maintains multiple offices, and has many shareholders, all within the forum. The corporation earns tens of millions of dollars of revenue (or more) from forum activities. Perhaps the Court would still not permit the forum to exercise general jurisdiction; the point is only that Helicopteros, Goodyear and Daimler are poor authority for saying so because their facts are so different. Today, the question devolves to whether such a corporation is "essentially at home." 161

Such a case is far from hypothetical, as General Motors' Kansas operations make clear. ${ }^{162}$ Under the Goodyear-Daimler formulation, is GM "essentially at home" in Kansas? If the Court had limited that phrase to a corporation's state of incorporation or principal place of business, the answer would be no, because GM is a Delaware corporation with its principal place of business in Michigan. But the Court has now had two recent opportunities to announce that limitation, and it has not. There is, apparently, some level of corporate activity between those diversity-jurisdiction reference points and the outer bounds of Fourteenth Amendment due process that would support general jurisdiction, but the Court's opinions give no clue as to what such a case would look like. ${ }^{163}$

\section{Scholarship on General Jurisdiction}

One finds articles on general jurisdiction dating back at least half a century. ${ }^{164}$ The last quarter century has witnessed increased interest. ${ }^{165}$ It will not do to rehearse that scholarship, but it is informative

161. "Home" itself is a tricky concept. The law speaks variously of "residence" and "domicile," but the definition of "home" is simply, "[a] dwelling place." BLACK's LAw Dictionary 849 (10th ed. 2014) (emphasis added). Some people are wealthy enough to have many homes. Some corporations are large enough to have many places where they do huge amounts of business from permanent offices with many employees. Whether either of those situations counts as "essentially at home" is not discernible from Goodyear or Daimler. See generally Goodyear, 131 S. Ct. at 2846; Daimler, 134 S. Ct. at 746.

162. See supra notes $134-36$ and accompanying text.

163. It is a mistake to consider Perkins such a case. There the corporation had relocated its principal place of business, for the duration of World War II, to the forum. See Keeton v. Hustler Magazine, Inc., 465 U.S. 770, 780 n.11 (1984) ("Ohio was the corporation's principal, if temporary, place of business."); Perkins v. Benguet Consol. Mining Co., 342 U.S. 437, 447-48 (1952). See also supra text accompanying notes 145-148. That clearly falls under the Goodyear-Daimler view of a corporation's home. See supra note 48. Accord, Borchers, supra note 3, at 1250-51 (footnote omitted) ("In Perkins, the corporate defendant temporarily relocated its headquarters from the Philippines to Ohio during World War II.").

164. See e.g., Arthur T. von Mehren \& Donald T. Trautman, Jurisdiction to Adjudicate: A Suggested Analysis, 79 Harv. L. Rev. 1121 (1966); Geoffrey C. Hazard, Jr., A General Theory of State-Court Jurisdiction, 1965 Sup. CT. Rev. 241.

165. See, e.g., Emily Eng, A New Paradigm: Domicile as the Exclusive Basis for the Exercise of General Jurisdiction over Individual Defendants, 34 CARDOZO L. REv. 845 
to look at the factors scholars think should determine whether general jurisdiction is constitutional. ${ }^{166}$

Professor Brilmayer and her colleagues focused on four considerations: (1) convenience for the defendant, (2) convenience of the plaintiff, (3) state power, and (4) reciprocal benefits and burdens. ${ }^{167}$ They concluded that, "[o]n balance, the reciprocal benefits and burdens rationale provides the most satisfactory basis for the state's exercise of coercive power."168 They also articulated a comparative way of looking at general jurisdiction: "[T]he due process clause should permit general jurisdiction on the basis of activities when the defendant reaches the quantum of local activity in which a purely local company typically would engage."169 Note that the comparison is between the foreign corporation's forum contacts and those of a local business concededly "at home," not between the foreign corporation's forum contacts and its contacts elsewhere in the world, as Daimler would have it. ${ }^{170}$ Consider the cases I posited earlier involving massive in-state contacts of a foreign corporation having its principal place of business and state of incorporation elsewhere. ${ }^{171}$ It seems difficult to say with a straight face that it is "fair play and substantial justice" "172 to exercise general jurisdiction over an out-of-state corporation that does all of its annual $\$ 50,000$ business in the forum to jurisdiction but some-

(2012); Sarah R. Cebik, "A Riddle Wrapped in a Mystery Inside an Enigma”: General Personal Jurisdiction and Notions of Sovereignty, 1998 AnN. Surv. Am. L. 1; Brilmayer, supra note 106 at 734.

166. Professor Twitchell suggested that the terms "specific jurisdiction" and "general jurisdiction" had insufficient and overlapping definitions and argued that one should speak instead of "dispute-specific" and "dispute-blind" jurisdiction. See Twitchell, supra note 146, at 611-13. On the other hand, Goodyear and Daimler demonstrate that the Court has not taken her advice on terminology. See generally Goodyear, 131 S. Ct. at 2846; Daimler, 134 S. Ct. at 746.

167. See Brilmayer et al., supra note 106, at 730-32. Professor Andrews is in substantial agreement with those factors. See Andrews, supra note 27, at 1022-25 (considering (1) reciprocity - a rough balance of benefits and burdens, (2) predictability, (3) sovereignty, and (4) convenience).

168. See Brilmayer et al., supra note 106, at 733. "[T] he reciprocal benefits rationale obtains when the defendant carries out substantial activities, which implicate the police powers and public facilities of the state." Id. at 741.

169. Id. at 742. Justice Sotomayor's opinion in Daimler explicitly adopted this approach. Daimler, 134 S. Ct. at 769 (Sotomayor, J., concurring in the judgment).

170. Id. at 734 ("[A]n absolute quantum of activity in a forum may give rise to jurisdiction.").

We should not treat defendants as less amenable to suit merely because they carry on more substantial business in other states; with one possible qualification, noted immediately below, the amount of activity elsewhere seems virtually irrelevant to any of the convenience or fairness policies underlying the imposition of general jurisdiction over a defendant. Id. at 742 .

171. See supra notes $136,160-165$ and accompanying text.

172. Int'l Shoe Co. v. Washington, 326 U.S. 310, 316 (quoting Milliken v. Meyer, 311 U.S. 457, 463 (1940)). This part of the Court's opinion drew extended adverse comment from Justice Black. See id. at 324 (Black, J., concurring). 
how unfair to do that to another out-of-state corporation doing more than 100 times that amount of forum business.

Part of the difficulty lies in the amorphousness of "fair play" and "substantial justice." What do those terms mean? Perhaps that question is unanswerable in all but the most formalistic (and circular) terms. Note that the Court, though ostensibly applying that standard since 1945, has never even attempted to define those terms with respect to general jurisdiction. Instead, it merely labels the connection between the defendant and the forum in each case "sufficient" or "insufficient." The Court discusses contacts but offers no identifiable standard to provide guidance to lower courts, counsel, or parties. Unfortunately, it is, reminiscent of Justice Stewart's famous comment about "obscenity" in his Jacobellis v. Ohio concurrence:

I shall not today attempt further to define the kinds of material I understand to be embraced within that shorthand description; and perhaps I could never succeed in intelligibly doing so. But I know it when I see it, and the motion picture involved in this case is not that. ${ }^{173}$

Apparently the Court knows fair play and substantial justice when it sees them, ${ }^{174}$ but with respect to general jurisdiction, it has never defined them. Goodyear and Daimler might have been steps in the right direction, but both cases lack specificity, which Daimler highlighted by cautioning against an overly narrow reading of Goodyear. ${ }^{175}$ Professor Twitchell pointed out:

As with every jurisdiction question, the more ad hoc it becomes, the more costly and less predictable it is. Most courts and commentators have abandoned the attempt to rationalize the policies supporting general jurisdiction, concluding instead that any corporation engaged in continuous and substantial business in the forum is automatically subject to 'insider' status. In using this adumbrated test,

173. Jacobellis v. Ohio, 378 U.S. 184, 197 (1964) (Stewart, J., concurring).

174. Justice Scalia took Justice Brennan to task for relying on "contemporary notions of due process" in Burnham:

The "contemporary notions of due process" applicable to personal jurisdiction are the enduring "traditional notions of fair play and substantial justice" established as the test by International Shoe. By its very language, that test is satisfied if a state court adheres to jurisdictional rules that are generally applied and have always been applied in the United States.

But the concurrence's proposed standard of "contemporary notions of due process" requires more: It measures state-court jurisdiction not only against traditional doctrines in this country, including current state-court practice, but also against each Justice's subjective assessment of what is fair and just. Authority for that seductive standard is not to be found in any of our personal jurisdiction cases. It is, indeed, an outright break with the test of "traditional notions of fair play and substantial justice," which would have to be reformulated "our notions of fair play and substantial justice."

Burnham v. Superior Court, 495 U.S. 604, 622-23 (1990) (Scalia, J., concurring in the judgment).

175. See supra text accompanying note 138. 
courts often overlook the key language in International Shoe qualifying the continuous and substantial standard: "[T]here have been instances in which the continuous corporate operations within a state were thought so substantial and of such a nature as to justify suit against it on causes of action arising from dealings entirely distinct from those activities." 176

All Goodyear and Daimler definitively reveal is that "more" was necessary than those cases had.

\section{Whither International Shoe's Theory?}

Goodyear and Daimler seem to have clawed back some of the jurisdictional latitude that International Shoe bequeathed. ${ }^{177}$ Some believe that "the Court meant what it said in Goodyear: general jurisdiction should be limited, except in an exceptional case, to a corporation's state of incorporation and principal place of business." ${ }^{178}$ Others take the position that the Court could not have meant what it said. ${ }^{179}$ If that were the only disagreement, Goodyear would have broken no theoretical ground, as Professor Borchers suggested shortly after the Court announced it. ${ }^{180}$

176. Twitchell, supra note 146 , at $674-75$ (footnotes omitted).

177. See Daimler AG v. Bauman, 134 S. Ct. 746, 761 n.18 (2014) (citations omitted) (disparaging plaintiffs' reliance on Barrow S.S. Co. v. Kane, 170 U.S. 100 (1898) and Tauza v. Susquehanna Coal Co., 115 N.E. 915 (1917)).

[B]oth [were] cited in Perkins . . . just after the statement that a corporation's continuous operations in-state may suffice to establish general jurisdiction. . . . See also International Shoe, 326 U.S. at 318 . . (citing Tauza). Barrow and Tauza indeed upheld the exercise of general jurisdiction based on the presence of a local office, which signaled that the corporation was "doing business" in the forum. Perkins' unadorned citations to these cases, both decided in the era dominated by Pennoyer's territorial thinking, . . . Id. should not attract heavy reliance today.

178. Donald Earl Childress III, General Jurisdiction After Bauman, 66 VAND. L. Rev. En BANC 197, 199 (2014) (footnote omitted).

Despite the lack of fireworks in the Court's opinion, Goodyear seems likely to have far-reaching effects on both the doctrine and theory of general jurisdiction. ... Goodyear added what appears to be a significant new hurdle to what must be shown to establish general jurisdiction, requiring that the defendant corporation's "affiliations" with the state be sufficient "to render [it] essentially at home in the forum State.").

Feder, supra note 48, at 672 (citation omitted).

179. See, e.g., Borchers, supra note 3 , at 1267 :

It seems unlikely, however, based on the Court's description of Goodyear USA's contacts that it would have failed to find general jurisdiction over it. Rather, the opinion's language juxtaposed Goodyear USA's extensive contacts with North Carolina for the rhetorical value of contrasting them with the relatively sparse contacts of its subsidiaries. The clear implication was that the contacts of Goodyear USA were well on the constitutional side of the line while the contacts of the subsidiaries placed them well on the other side.

180. See id. at 1266 ("At a theoretical level, Goodyear is trivial. The opinion is little more than an exercise in reasoning by analogy."). 
But there is more. Daimler added an entirely new dimension to the general-jurisdiction inquiry. Contacts still count, but one cannot simply count contacts. The advent of relative contacts complicates the general-jurisdiction inquiry. ${ }^{181}$ One must now consider more factors than how long the corporate defendant has maintained contact with the forum, how many employees it has there, its real estate holdings, its business expenditures, and its income. One must weigh those contacts against the corporation's global activities to see whether they are a large enough percentage to make the corporation constructively "at home." That makes the general-jurisdiction inquiry murky with respect to giant corporations in Daimler's aftermath. ${ }^{182}$

International Shoe did not mention anything resembling relative contacts, nor did Tauza. ${ }^{183}$ Perkins, which both Goodyear and Daimler cite as the paradigmatic general-jurisdiction case for corporations, makes only a fleeting reference to the defendant's overall business, and that reference cuts against Daimler's relative contacts approach. ${ }^{184}$ Similarly, Helicopteros gave no hint of a relative-contacts approach, noting:

Even when the cause of action does not arise out of or relate to the foreign corporation's activities in the forum State, due process is not offended by a State's subjecting the corporation to its in personam jurisdiction when there are sufficient contacts between the State and the foreign corporation. ${ }^{185}$

There is nothing here of how much business activity Helicopteros did outside of Texas, or what percentage of its total business activity occurred in Texas. The discussion is only of "sufficient" contacts. International Shoe made clear that one must consider both the quantity

181. See supra note 43 and accompanying text; see also Daimler, 134 S. Ct. at 763-64 (Sotomayor, J., concurring in the judgment).

182. I use "aftermath" advisedly. After Daimler, "math" does indeed appear to be central. See Daimler, 134 S. Ct. at 758-62.

183. See supra note 19 and accompanying text; see also Int'l Shoe Co. v. Washington, 326 U.S. 310 (1945). International Shoe was what one refers to today as a specific-jurisdiction case. Tauza, obviously, was not, and although Judge Cardozo made no mention of the corporate defendant's non-New York business, one might speculate that as a Pennsylvania corporation with its principal place of business in Pennsylvania, it did far more business there than in New York, an inference supported by the limited nature of Susquehanna Coal's New York operation. See supra note 19 and accompanying text.

184. See Perkins v. Benguet Consol. Min. Co., 342 U.S. 437, 438 (1952) (referring to Benguet's "continuous and systematic, but limited, part of its general business"). Justice Sotomayor was blunt: "At no point did we attempt to catalog the company's contacts in forums other than Ohio or to compare them with its Ohio contacts. If anything, we intimated that the defendant's Ohio contacts were not substantial in comparison to its contacts elsewhere." Daimler, 134 S. Ct. at 768 (Sotomayor, J., concurring in the judgment).

185. Helicopteros Nacionales de Colom., S.A. v. Hall, 466 U.S. 408, 414 (1984) (footnote and citations omitted). "In no sense did our analysis turn on the extent of the company's operations beyond Texas." Daimler, 134 S. Ct. at 768 (Sotomayor, J., concurring in the judgment). 
and quality of forum contacts, ${ }^{186}$ but Daimler's relative-contacts approach is exclusively quantitative. ${ }^{187}$

Even Goodyear, far closer in time to Daimler and heard by the same Court, offered only vague hints of what one might construe, in retrospect, to be a reference to relative contacts. ${ }^{188}$

To the extent that the company was conducting any business during and immediately after the Japanese occupation of the Philippines, it was doing so in Ohio: the corporation's president maintained his office there, kept the company files in that office, and supervised from the Ohio office "the necessarily limited wartime activities of the company." 189

One doubts that even Einstein would view this as a discussion of relativity. And Goodyear's discussion of Helicopteros invokes no comparison of Texas versus non-Texas contacts, noting only that the defendant expended "substantial sums" to purchase helicopters, training, and other equipment in the forum. ${ }^{190}$

Daimler leaves a critical question open. The relative-contacts approach now seems to be important, but it is unclear to what sorts of cases it applies. Perhaps it applies only to corporations chartered outside the United States, though nothing in Daimler suggests that, and it would be odd for the Court to introduce a special method of analysis for such corporations. International Shoe's "fair play and substantial justice" approach is broad enough to encompass consideration of corporate alienage.

If the relative-contacts approach is now how the Court will assess claims of general jurisdiction over corporations, then Daimler is startling, for the Court will have ratified the concept that Justice Sotomayor's Daimler concurrence characterized as "too big for general jurisdiction." ${ }^{191}$ Most giant corporations will not be subject to general jurisdiction except where chartered or at their principal places of business. Much smaller corporations with the bulk of their activities in a forum other than those two diversity-derived referents will be subject to general jurisdiction with far fewer contacts.

There will be some practical effects as well. The relative-contacts approach will force a plaintiff contemplating suit against a corporation

186. See Int'l Shoe, 326 U.S. at 319.

187. Daimler, 134 S. Ct. at 761-63.

188. Goodyear, 131 S. Ct. at 2852 (noting that "a small percentage of petitioners' tires (tens of thousands out of tens of millions manufactured between 2004 and 2007) were distributed within North Carolina by other Goodyear USA affiliates."). But see Daimler, 134 S. Ct. at 768 (Sotomayor, J., concurring in the judgment) ("Just as in Perkins and Helicopteros, our opinion in Goodyear did not identify the defendants' contacts outside of the forum State, but focused instead on the defendants' lack of offices, employees, direct sales, and business operations within the State.").

189. Goodyear, 131 S. Ct. at 2856 (quoting Perkins, 342 U.S. at 447-48).

190. Id.

191. Daimler, 134 S. Ct. at 764 (Sotomayor, J., concurring in the judgment). 
in a forum other than its charter state or principal place of business to undertake more pre-action and pre-trial discovery with respect to the extent of the defendant's global activities. ${ }^{192}$ Jurisdictional inquiries will become more protracted. Courts and litigants will spend more resources on issues other than the merits. Minimum contacts, far from a bright-line standard from its inception, will become even more blurry. At this point, the Daimler footnote ${ }^{193}$ is all the guidance the lower courts have. The Court's effort to limit general jurisdiction over corporations has opened the courthouse doors to far more jurisdictional litigation.

Goodyear and Daimler create another important issue. The Court's effort to curb general jurisdiction over corporations compels asking whether those two cases will affect general jurisdiction over individuals. The question is acute when jurisdiction rests on nothing more than the individual's receipt of the summons and complaint while present in the forum-transient jurisdiction. Goodyear and Daimler connote that it is impossible for transient jurisdiction to continue to rest on temporary presence alone, at least if the Court's jurisdictional approach is to retain any consistency.

\section{Dropping the Other Shoe: Goodyear's and Daimler's IMPLICATIONS AND BURNHAM's Flat TIRE}

Are corporations people? In Bank of the United States v. Deveaux, Chief Justice Marshall and his colleagues unanimously declared that corporations are not citizens for diversity purposes. ${ }^{194}$ The Court ac-

192. Trial judges may regard such discovery as "fishing expeditions." See, e.g., United States v. Nixon, 418 U.S. 683 (1974) (referring disparagingly to an unbounded, speculative demand in a subpoena duces tecum); BLACK's LAW DictionARY 754 (10th ed. 2014) ("An attempt, through broad discovery requests or random questions, to elicit information from another party in the hope that something relevant might be found; esp., such an attempt that exceeds the scope of discovery allowed by procedural rules") Justice White's concurrence in Burnham however, seemed to contemplate precisely that kind of inquiry:

$[\mathrm{T}]$ here has been no showing here or elsewhere that as a general proposition the rule is so arbitrary and lacking in common sense in so many instances that it should be held violative of due process in every case. Furthermore, until such a showing is made, which would be difficult indeed, claims in individual cases that the rule would operate unfairly as applied to the particular nonresident involved need not be entertained. At least this would be the case where presence in the forum State is intentional, which would almost always be the fact. Otherwise, there would be endless, fact-specific litigation in the trial and appellate courts, including this one.

Burnham v. Superior Court, 495 U.S. 604, 628 (1990) (White, J., concurring in part and concurring in the judgment). The Court's relative-contacts approach presents the prospect of exactly the sort of endless, fact-specific litigation that Justice White feared.

193. See Daimler, 134 S. Ct. at 762 n.20.

194. Bank of U.S. v. Deveaux, 9 U.S. (5 Cranch) 61 (1809).

That invisible, intangible, and artificial being, that mere legal entity, a corporation aggregate, is certainly not a citizen; and, consequently, cannot sue or 
knowledged diversity jurisdiction, not using any concept of corporate citizenship, but rather on the basis of the citizenships of the corporation's members. ${ }^{195}$ Yet, the Court recognized that well established English law regarded corporations as inhabitants either by reason of residence or by "having lands or tenements in any shire."196 Thus, at common law, corporations could be present.

For purposes of diversity jurisdiction, corporations became both citizens and people.

A corporation created by a state to perform its functions under the authority of that state and only suable there, though it may have members out of the state, seems to us to be a person, though an artificial one, inhabiting and belonging to that state, and therefore entitled, for the purpose of suing and being sued, to be deemed a citizen of that state. ${ }^{197}$

Chief Justice Marshall and his colleagues regretted Deveaux's contrary ruling on citizenship. ${ }^{198}$ Over time, corporations acquired more

be sued in the courts of the United States, unless the rights of the members, in this respect, can be exercised in their corporate name. If the corporation be considered as a mere faculty, and not as a company of individuals, who, in transacting their joint concerns, may use a legal name, they must be excluded from the courts of the union.

Id. at $86-87$.

195. Id. at $87-88$.

196. Id. at 89 (quoting Henry VIII's "Bridges Act" as recorded in Coke's statutory compilation and citing King v. Gardner, 1 Cowper 79, 83 (1774)). See also 22 Hen. VIII c.5, on which Lord Coke relied; Sir Edward Coke, The Second Part of the Institutes of the Lawes of England, 2 Inst. 697, 702 (Garland Publishing, Inc. 1979).

[A]lthough a man be dwelling in an house in a foraigne County, Riding, City, or Towne corporate, yet if he hath lands or tenements in his own possession and manorance in the County, Riding, City, or Towne corporate, where the decayed bridge is, he is an inhabitant, both where his person dwelleth, and where he hath lands or tenements in his owne possession within this statute.

22 Hen. VIII c.5.

197. Louisville, Cincinnati \& Charleston R.R. v. Letson, 43 U.S. (2 How.) 497, 555 (1844).

198. Id. at $555-56$.

$[T]$ he cases of Strawbridge and Curtiss and the Bank and Deveaux have never been satisfactory to the bar, and that they were not, especially the last, entirely satisfactory to the court that made them. They have been followed always most reluctantly and with dissatisfaction. By no one was the correctness of them more questioned than by the late chief justice who gave them. It is within the knowledge of several of us, that he repeatedly expressed regret that those decisions had been made, adding, whenever the subject was mentioned, that if the point of jurisdiction was an original one, the conclusion would be different. We think we may safely assert, that a majority of the members of this court have at all times partaken of the same regret, and that whenever a case has occurred on the circuit, involving the application of the case of the Bank and Deveaux, it was yielded to, because the decision Id. had been made, and not because it was thought to be right. 
and more of the aspects of corporeal beings. In 1886, the Court recognized corporations as persons within the meaning of the Fourteenth Amendment. ${ }^{199}$ By 1906, corporations had Fourth Amendment rights. ${ }^{200}$ Twenty-five years later, even alien corporations were entitled to Fifth Amendment due process ${ }^{201}$ and, subsequently, to the protection of the Double Jeopardy Clause. ${ }^{202}$ Most recently, the Court reconfirmed the First Amendment rights of free speech ${ }^{203}$ and petition, ${ }^{204}$ and a sharply divided Court declared that they are entitled also to free exercise of religion. ${ }^{205}$ Thus, corporations have, over time, acquired more and more of the constitutional protections enjoyed by individuals.

Goodyear and Daimler demonstrate, however, that corporations have not acquired the same constitutional responsibilities as individuals. ${ }^{206}$ The Fourteenth Amendment protection they enjoy from state jurisdictional assertions is far broader than that of individuals. Daimler underscores the inconsistency of the Court's approaches to general jurisdiction over corporations versus individuals.

Goodyear made clear that only a limited set of affiliations with a forum will render a defendant amenable to all-purpose jurisdiction there. "For an individual, the paradigm forum for the exercise of general jurisdiction is the individual's domicile; for a corporation, it is an equivalent place, one in which the corporation is fairly regarded as at home." ... With respect to a corporation, the place of incorporation and principal place of business are "paradig[m] . . bases for general jurisdiction.",207

199. See Santa Clara Cnty. v. S. Pac. R.R., 118 U.S. 394, 396 (1886) (statement of Waite, Ch. J.).

The court does not wish to hear argument on the question whether the provision in the Fourteenth Amendment to the Constitution, which forbids a State to deny to any person within its jurisdiction the equal protection of the Id. laws, applies to these corporations. We are all of opinion that it does.

200. See Hale v. Henkel, 201 U.S. 43, 76 (1906) (finding no Fourth Amendment violation).

201. See Russian Volunteer Fleet v. United States, 282 U.S. 481, 489 (1931).

202. See United States v. Martin Linen Supply Co., 430 U.S. 564 (1977).

203. See Citizens United v. Fed. Elections Comm'n, 558 U.S. 310, 345 (2010) (citing First Nat'l. Bank v. Bellotti, 435 U.S. 765, 778 n.18 (1978)).

204. See Citizens United, 558 U.S. at 355 (citing Bellotti, 435 U.S. at 784; Cal. Motor Transp. Co. v. Trucking Unlimited, 404 U.S. 508, 510-11 (1972); E. R.R. Presidents Conference v. Noerr Motor Freight, Inc., 365 U.S. 127, 137-38 (1961)).

205. See Burwell v. Hobby Lobby Stores, Inc., 134 S. Ct. 2751 (2014).

206. See Roger M. Michalski, Rights Come with Responsibilities: Personal Jurisdiction in the Age of Corporate Personhood, 50 SAn Diego L. Rev. 125, 127 (2013) (footnote omitted) ("Corporate personhood is a place where courts have split rights and obligations asunder to dangerous effect. Nowhere is this divorce more visible, consequential, and its effect more painful than in the personal jurisdiction doctrine.").

207. Daimler AG v. Bauman, 134 S. Ct. 746, 760 (2014) (citing Goodyear Dunlop Tires Operations, S.A. v. Brown, 131 S. Ct. 2853-54 (2011)); Brilmayer, supra note 106, at 728; Twitchell, supra note 146, at 633. 
Having thus equated individuals and corporations with respect to domicile and general jurisdiction, the Court has not explained the chasm between its general-jurisdiction jurisprudence with respect to each. Burnham v. Superior Court unanimously (though lacking any majority rationale) ruled that an individual is amenable to general jurisdiction in any state where she receives service of process. ${ }^{208}$ Presence "counts" for general jurisdiction over individuals. Although the Court is no doubt loath to admit it, it rests general jurisdiction over corporations on a thinly masked concept of presence, limiting it to three categories, one of them as yet undefined: (1) place of incorporation, (2) principal place of business, (3) the exceptional case that Daimler said Goodyear did not exclude. ${ }^{209}$ If the test for general jurisdiction for corporations is domicile or where the corporation is "essentially at home," why do the same limitations not apply to individuals?

Consider the almost-twin cases of Burnham ${ }^{210}$ and Kulko. ${ }^{211}$ The Kulkos married in California, though both were then (and remained) domiciled in New York. When they separated, they agreed that their two children would live with the father in New York during the school year and with the mother in California during the summer. The daughter later decided she wanted to reverse that arrangement, so the father bought her a one-way ticket to California. Subsequently, the son also wanted to live most of the year in California. He went there, unbeknownst to the father, on a ticket that the mother purchased. The mother sued in California for modification of the divorce decree to transfer custody and for increased support. The father resisted jurisdiction, and a majority found his contacts with California insufficient. $^{212}$

The Burnhams were married in West Virginia, moved to New Jersey, and had two children. ${ }^{213}$ The wife moved to California with the children, where she commenced a divorce action. ${ }^{214}$ When the husband was in California for three days on business and to see the children, he received service in the divorce action, after which he returned to New Jersey. ${ }^{215}$ The Court unanimously upheld jurisdiction. ${ }^{216}$ Justice Scalia's opinion for four Justices relied entirely on

208. Burnham v. Superior Court, 495 U.S. 604 (1990).

209. See supra text accompanying note 138.

210. See Burnham v. Superior Court, 495 U.S. 604 (1990).

211. See Kulko v. Superior Court, 436 U.S. 84 (1978).

212. Id. Justice Brennan dissented in a one-paragraph opinion. Id. at 101-02. Although he declined to characterize the majority's "determination against state-court in personam jurisdiction [a]s implausible," he offered no rationale of his own other than that his "independent weighing of the facts," caused him to find in favor of jurisdiction. Id. at 102 (Brennan, J., dissenting).

213. Burnham, 495 U.S. at 608.

214. Id.

215. Id. at $608-23$.

216. See id. at $627,628$. 
what it characterized as the centuries-long tradition of basing jurisdiction on service of process on an individual present in the forum. ${ }^{217}$ For him, that made jurisdiction "consistent with traditional notions of fair play and substantial justice." 218 Justice Brennan's opinion (also for four Justices) relied on the defendant's having visited the forum for three days as satisfying the purposeful-availment requirement, ${ }^{219}$ for which Justice Scalia took Justice Brennan to task. ${ }^{220}$

No one would suggest that Burnham was "at home" in California. He was no more at home in California than was Kulko, yet the Court held that there was general jurisdiction over Burnham but not Kulko. ${ }^{221}$ Apparently, simply receiving a summons in the forum renders the individual "at home." Of course, the Goodyear and Daimler Courts used the essentially-at-home formulation to locate a corporation, not an individual, but it is difficult to justify viewing individuals and corporations differently for International Shoe purposes. The mind balks at saying that Burnham or Kulko had jurisdiction-justifying contacts with California but that giant corporations operating on massive scales there every day may not. ${ }^{222}$

The current Court may deny that it has retreated to the pre-Shoe concept of corporate "presence," but its current test for general jurisdiction over corporations speaks in quintessentially geographic terms. "Home" may be where the heart is, ${ }^{223}$ but it is a place. When Goodyear and Daimler speak of a corporation being "essentially at home," they speak of corporate presence in a place. The Court has decided that for most jurisdictional purposes, a corporation is at home only where it is incorporated or has its principal place of business.

The idea that a corporation is forever at home in the state that incorporated it makes no more sense than saying that an individual is forever at home in her state of birth. People's birth certificates reflect

217. Id. at 610-13 (Scalia, J., concurring in the judgment). Justice Brennan disputed that view. Id. at 633-35 (Brennan, J., concurring in the judgment). Professor Hazard agreed with Justice Brennan about how well established transient jurisdiction was in England. Hazard, supra note 164, at 255. "The defendant's presence in England seems to have been less a reason for asserting jurisdiction than an obviation of a reason why it should not be asserted; it could hardly be said that personal presence was the basis for jurisdiction." Id. 316).

218. Burnham, 495 U.S. at 619 (quoting Int'l Shoe Co. v. Washington, 326 U.S. 310,

219. Id. at 637-39 (Brennan, J., concurring in the judgment). Of course, Kulko had more than visited California; he celebrated his marriage there. Kulko v. Superior Ct., 436 U.S. 84 (1978). Perhaps that is what caused Justice Brennan to dissent in Kulko, but he was silent about his reasons. See Burnham, 495 U.S. at 637-39.

220. Id. at 623-24 (Scalia, J., concurring in the judgment).

221. See id. at 627-628.

222. Recall that Burnham was only in California for three days. Burnham, 495 U.S. at 624. See supra text accompanying notes 212-217.

223. See generally Christine Gledhill, Home Is Where the Heart Is (1987); Joseph C. Neal, Singleton Snippe. Who Married for a Living, 30 Graham's Am. Monthly Mag. 165, 166 (1847). 
the state of birth, not the state of domicile. ${ }^{224}$ Many corporations have Delaware charters ${ }^{225}$ but conduct little or no corporate business in Delaware. ${ }^{226}$

The Court attempted to distinguish between individuals and corporations because corporations' actions may be systematic, continuous and voluminous in many places simultaneously, while individuals can be in only one place at a time. That misses the point, however. Individuals may travel to several states in a single day and are subject to general jurisdiction in each state if they receive service of process while there.

The Court's insistence that it is applying International Shoe's minimum-contacts analysis causes the problem. An individual may be present in a state only fleetingly — changing planes at a hub 227 - and be subject to general jurisdiction if the individual receives process in the airport. Justice Scalia would argue that presence plus service is a (perhaps the) traditional basis for jurisdiction and needs no other justification. Justice Brennan presumably would argue that the defendant purposefully availed himself of the benefits of the forum by using the hub. ${ }^{228}$ But what about the case of a defendant whose flight is diverted from one state's airport to another's? If that defendant receives process in the airport, what would those two combatants from

224. For example, couples living in New Jersey may go to New York or Pennsylvania hospitals for the birth of their children.

225. Former Dean of Stanford Law School Bayless Manning offered the following reasoning on why this is so:

We, as practitioners, do not go to Delaware to incorporate and to litigate primarily because the law is "favorable" (whatever that may mean). We go to Delaware because there is a vast corpus of sophisticated law there and a lot of people in the right positions who know what it is all about.

....

[M]y Delaware counsel and I will have a wide ranging and sophisticated body of corporation law-a jurisprudence if you will - to bring to bear on almost any problem that will arise. No other jurisdiction can provide so much. And that is why Delaware is, in fact, national, and why its own gravitational pull tends to attract more companies each year and thereby further reinforce its preeminence.

Bayless Manning, State Competition: Panel Response, 8 CARdozo L. Rev. 779, 785-86 (1987).

226. Id. at 783 ("The way we know that [Delaware] law is national is simply by noting the number of companies that are incorporated in Delaware but have no other link to that state. One need only add up the incorporation numbers of the Fortune 500 companies from state to state.").

227. Even being in the airspace over a forum may suffice, raising (so to speak) the question that many young children ask: "how high is up?" See Grace v. MacArthur, 170 F. Supp. 442 (E.D. Ark. 1959).

228. See Burnham, 495 U.S. at 637-38 (Brennan, J., concurring in the judgment). Justice Scalia argued that should have led Justice Brennan to uphold jurisdiction over the individual irrespective of the locus of service. See id. at 623-24 (Scalia, J., concurring in the judgment). See infra note 286. 
Burnham 229 have to say about the propriety of exercising

The curious thing about Goodyear and Daimler is their insistence on equating corporations with individuals for some contacts purposes but not others. "For an individual, the paradigm forum for the exercise of general jurisdiction is the individual's domicile; for a corporation it is an equivalent place, one in which the corporation is fairly regarded as home."231 Fair enough, but both cases glide effortlessly from that premise to the conclusion that a corporation is amenable to general jurisdiction only where it is essentially at home. ${ }^{232}$ That, too, is plausible, but the Court cannot explain why the approach should not be the same with respect to general jurisdiction over individuals.

229. See supra note 16.

230. Both might come out the same way, but their positions might be more difficult to justify. For Justice Brennan, there is no question that the defendant received significant benefits from the forum: a safe place to land. On the other hand, it is harder to argue that there was "purposeful" availment. Justice Scalia's Burnham opinion appeared to allow only minimal exceptions to the presence rule-cindividuals who were brought into the forum by force or fraud . . . or who were there as a party or witness in unrelated judicial proceedings." Burnham, 495 U.S. at 613 (Scalia, J., concurring in the judgment). Perhaps Justice Scalia would regard the diverted-flight case as one where the individual's presence was by force. However, the force to which the statutes and case on which he relied adverted was force by or on behalf of the plaintiff. See Wanzer v. Bright, 52 Ill. 35, 40 (1869).

Consider a state statute that denied entry to citizens of other states unless they appointed a designated state official as their agent for service of process on any claim, whether related to the state or not, for the time that the individual was in the state. The Court would undoubtedly find such a statute unconstitutional as a burden on the right to travel. See Shapiro v. Thompson, 394 U.S. 618, 629-30 (1969) overuled on other grounds, Edelman v. Jordan, 415 U.S. 651 (1974). See also United States v. Guest, 383 U.S. 745, 757-58 (1966); Smith v. Turner, 48 U.S. (7 How.) 283, 492 (1849). Kane v. New Jersey, 242 U.S. 160, 160 (1916) upheld an explicit appointment requirement, but the appointment was only for claims arising out of a non-resident's driving in New Jersey, not for all claims. Hess v. Pawloski, 274 U.S. 352, 356-57 (1927) upheld implicit appointment, but the statute there had the same restrictions as the statute in Kane. See Chapter 90, General Laws of Massachusetts, as amended by Stat. 1923, c. 431, § 2, reprinted in Hess, 274 U.S. at 354. Justice Butler's opinion in Hess noted that individuals have a constitutionally protected right to be in any state and to transact business there, Hess, 274 U.S. at 355-56 (citing U.S. Const. art. IV, § 2, cl. 1), and, further, that "[ $\mathrm{t}]$ he mere transaction of business in a state by nonresident natural persons does not imply consent to be bound by the process of its courts." Id. at 355 (citing Flexner v. Farson, 248 U.S. 289 (1919)).

[A] state in effect may require an individual's consent to specific jurisdiction as a condition of driving or doing business within the state. But a state may not reasonably require this individual, as a condition for mere entry or occasional business, to consent to general jurisdiction over litigation arising outside of the state.

Brilmayer et al., supra note 106, at 771. If a state cannot extract consent to general jurisdiction explicitly or implicitly from an individual's presence in the state to transact business, then how can general jurisdiction exist simply by virtue of the individual's presence?

231. See Daimler AG v. Bauman, 134 S. Ct. 746, 760 (2014).

232. Id. at 761 (quoting Goodyear Dunlop Tires Operations, S.A. v. Brown, $131 \mathrm{~S}$. Ct. 2846, 2851 (2011)). 
There are two possible answers. First, perhaps an individual's physical presence is "special" because of the history to which Justice Scalia adverted in Burnham ${ }^{233}$ and that Justice Brennan disputed. ${ }^{234}$ Second, perhaps Justice Scalia's view of International Shoe's minimumcontacts approach as applying only to absent defendants ${ }^{235}$ is correct. ${ }^{236}$ Neither answer explains why the Court views corporations as present for jurisdictional purposes only at their "domiciles" or "essential" homes but individuals present wherever a process server may find them.

Corporations are no more physically "present" at their essential homes than anywhere else. The Court uses those locations as presence proxies; they serve, as Justice Ginsburg said, as analogies to an individual's domicile. ${ }^{237}$ Although an individual can have only one domicile at a time, ${ }^{238}$ a corporation can have two for purposes of diversity jurisdiction. ${ }^{239}$ Consider, however, what makes a corporation's principal place of business in a state where it is not incorporated its "domicile." It cannot be merely its legal affiliation with the state because the only formal affiliation it can have is an authorization to do

233. Burnham, 495 U.S. at 610-16 (Scalia, J., concurring in the judgment). But see infra notes 278-282 and accompanying text.

234. See Citizens United v. Fed. Elections Comm'n, 558 U.S. 310, 345 (2010) (citing First Nat'l Bank v. Bellotti, 435 U.S. 765, 778 n.18 (1978)).

235. Id. at 620 (opinion of Scalia, J.).

236. Justices Scalia and Brennan clashed sharply over that view. Justice Scalia viewed Shaffer as a very limited decision that neither said nor implied anything about transient jurisdiction. Justice Brennan relied heavily on Justice Marshall's statement in Shaffer that, "[w]e therefore conclude that all assertions of state-court jurisdiction must be evaluated according to the standards set forth in International Shoe and its progeny." Shaffer v. Heitner, 433 U.S. 186, 212 (1977). See also Burnham, 495 U.S. at 630 (Brennan, J., concurring in the judgment).

237. Burnham v. Superior Court, 495 U.S. 604, 623-24 (1990).

238. Mitchell v. United States, 88 U.S. 350, 353 (1874).

A domicile once acquired is presumed to continue until it is shown to have been changed. Where a change of domicile is alleged the burden of proving it rests upon the person making the allegation. To constitute the new domicile two things are indispensable: First, residence in the new locality; and, second, the intention to remain there. The change cannot be made except facto et animo. Both are alike necessary. Either without the other is insufficient. Mere absence from a fixed home, however long continued, cannot work the change. There must be the animus to change the prior domicile for another. Until the new one is acquired, the old one remains. These principles are axiomatic in the law upon the subject.

Id. (footnotes omitted). See also Restatement (SEcond) of Conflict of Laws $\S 11(2) \mathrm{cmt}$. m (1971). Query whether, as the Court implied in Goodyear and Daimler, it is always appropriate to exercise jurisdiction over a domiciliary who has been absent from her domicile for some years and expects never to return. See, e.g., Mas v. Perry, 489 F.2d 896 (5th Cir. 1974). Professor Andrews demonstrates persuasively why the state of domicile's attempt to exercise general jurisdiction in such a case is manifestly unfair. See Andrews, supra note 27, at 1057-58. See also id. at 1081 ("This at-home standard applies to natural persons, but, contrary to the Court's dictum, it does not always align with legal domicile.").

239. See 28 U.S.C. $\$ 1332$ (c) (2012). 
business there. That hardly makes the principal place of business unique. Some corporations are authorized to do business in every state and in many foreign countries. The amount of corporate activity at sites other than the principal place of business may be substantially greater than activity at the principal place of business. To borrow from the Court's relative-contacts analysis, the amount of actual business a corporation does at its principal place of business may be only a tiny fraction of its nationwide or worldwide business.

For example, General Motors is a Delaware corporation with its principal place of business in Michigan. ${ }^{240}$ Its contacts with Michigan are extensive ${ }^{241}$ but it is unlikely that they are more than a small percentage of its United States business, much less its global business. Perhaps the Daimler relative-contacts approach suggests that GM is not "essentially at home" in Michigan even if it is formally at home there. ${ }^{242}$ Daimler's relative-contacts approach means that a corporation as large as GM may not be "essentially at home" anywhere.

Individuals are not "essentially at home" in any state to which they happen to journey. The Court functionally equates "essentially at home" with domicile, ${ }^{243}$ and requires a corporation to be essentially at home before a state can exercise general jurisdiction over it. Therefore, it should restrict general jurisdiction over individuals to their domiciles. The Court is trying to have the analysis both ways: it localizes corporate presence in a way unrelated to the corporation's local activity. Perhaps the difference between the Court's treatment of corporations and individuals is the corporeal-incorporeal dichotomy. If that is so, the Court should drop all pretense of speaking of corporate "contacts," for it is not contacts that "count" at all; it is the artifice of corporate domiciles.

International Shoe ushered in presence proxies. Recall the Court's words referring to the defendant: "if he be not present within the territory of the forum, he have certain minimum contacts with it such that the maintenance of the suit does not offend 'traditional notions of fair play and substantial justice." 244 It would be no more clear that the minimum-contacts approach recognized presence proxies if Chief Jus-

240. Selkirk v. Gen. Motors, LLC, No. 13-331, 2013 WL 3327377, at*3 n.3 (E.D. Pa. 2013).

241. In addition to its corporate headquarters, GM has five of its eleven U.S. manufacturing sites in Michigan. See General Motor Manufacturing Plants, GM Auth., http://gmauthority.com/blog/gm/gm-manufacturing/ (last visited Oct. 7, 2014).

242. A safer conclusion might be that the Court's construct for a corporation's principal place of business for diversity-jurisdiction purposes under 28 U.S.C. $\$ 1332$ (2012), see Hertz Corp. v. Friend, 559 U.S. 77, 77 (2010), is ill-suited for determinations of personal jurisdiction using Daimler's relative-contacts approach.

243. Daimler AG v. Bauman, 134 S. Ct. 746, 757 (2014) (citing Goodyear Dunlop Tires Operations, S.A. v. Brown, 131 S. Ct. 2846, 2857 (2011)).

244. Int'l Shoe Co. v. Washington, 326 U.S. 310, 316 (1945) (emphasis added) (quoting Milliken v. Meyer, 311 U.S. 457, 463 (1940)). The Court clearly intended Shoe's minimum-contacts analysis to apply to corporations and individuals; note the 
tice Stone had used the term explicitly. This view of International Shoe calls to mind Justice Scalia's Burnham opinion and its view of Shaffer v. Heitner:

Shaffer, like International Shoe, involved jurisdiction over an absent defendant, and it stands for nothing more than the proposition that when the "minimum contact" that is a substitute for physical presence consists of property ownership it must, like other minimum contacts, be related to the litigation. ${ }^{245}$

Whether Justice Scalia likes it or not, Shaffer changed a long established principle of due process, but not by announcing a new theory of due process. In Justice Scalia's view the Shaffer Court decided only that the presence in the state of property unrelated to the litigation was no longer constitutional as a presence proxy. ${ }^{246}$

In one way, Justice Scalia's characterization of Shaffer is quite narrow, for he spoke of "the "minimum contact" - singular-and so clearly was not addressing general jurisdiction. The first opportunity he had to consider that topic came in Goodyear. Yet, the Supreme Court recognized general jurisdiction as a category not once or twice, but three times. The first time was in International Shoe with its men-

use of "he" rather than "it." There was no individual defendant, and throughout the opinion, the Court referred to the corporation as "it." See generally id.

245. Burnham v. Superior Ct., 495 U.S. 604, 620 (1990) (Scalia, J., concurring in the judgment) (emphasis of "a substitute for physical presence" added). Professor Andrews characterized this as "avoiding Shaffer's holding that all assertions of jurisdiction must be assessed under minimum contacts analysis . . ." Andrews, supra note 27 , at 1057.

Justice Scalia's observation does little to obscure the incongruity of his apparent acceptance of Shaffer with his underlying constitutional theory about why mere presence in a state is sufficient even after International Shoe.

'[A] process of law, which is not otherwise forbidden, must be taken to be due process of law, if it can show the sanction of settled usage both in England and in this country; but it by no means follows that nothing else can be due process of law.... [That which], in substance, has been immemorially the actual law of the land ... therefor[e] is due process of law . . . '

The short of the matter is that jurisdiction based on physical presence alone constitutes due process because it is one of the continuing traditions of our legal system that define the due process standard of "traditional notions of fair play and substantial justice."

Burnham, 495 U.S. at 619 (quoting Hurtado v. California, 110 U.S. 516, 528 (1884)). One may agree or disagree with that approach to constitutional law, but the same argument is available with respect to quasi in rem jurisdiction, which was settled in usage for a very long time and that the Court had explicitly approved in Harris v. Balk, 198 U.S. 215 (1905), abrogated by Shaffer v. Heitner, 433 U.S. 186 (1977). See Burnham, 495 U.S. at 630-32 (Brennan, J., concurring in the judgment). For intellectual consistency, perhaps Justice Scalia should have disapproved Shaffer rather than distinguishing it.

246. In this respect, Justice Scalia is at war with himself and with Hurtado, on which he relied for his view of tradition's entitlement to continuation. 
tion of cases involving claims unrelated to the forum. ${ }^{247}$ The second was in Perkins, and the Court allowed general jurisdiction. The third was Helicopteros, although the Court did not find jurisdiction there:

Even when the cause of action does not arise out of or relate to the foreign corporation's activities in the forum State, due process is not offended by a State's subjecting the corporation to its in personam jurisdiction when there are sufficient contacts between the State and the foreign corporation. ${ }^{248}$

Thus, the category was well established; "sufficient contacts" were a presence proxy that allowed general jurisdiction. Goodyear and Daimler should not have changed that; ${ }^{249}$ both cases held only that the limited contacts between the European corporate defendants and the forums were insufficient. On that, the Court was unanimous. Justice Sotomayor castigated the Daimler majority for its dicta, not its holding. ${ }^{250}$ She saw no need to undertake a major redefinition of general jurisdiction gratuitously.

Nonetheless, the Court did exactly that, but in the process it made clear that corporate contacts no longer count in the way everyone has understood them since 1945. The sweeping language of Goodyear and Daimler suggests that it does not matter how much business a corporation does in the forum, or how many employees, manufacturing sites, or other offices it has there. All that matters is the formal affiliation that one might call "corporate domicile," (borrowing the analogy to individuals that the Court used) except in what Justice Ginsburg characterized as the extraordinary case..$^{251}$

General Motors has eleven manufacturing sites in the United States. ${ }^{252}$ Five are in Michigan, and there is one each in Indiana, Kansas, Kentucky, Missouri, Ohio, and Texas. Each facility is on a large site $^{253}$ and has been in operation for decades. ${ }^{254}$ The Kansas facility

247. See Int'l Shoe, 326 U.S. at 318 (referring to "continuous corporate operations within a state so substantial and of such a nature as to justify suit against it on causes of action arising from dealings entirely distinct from those activities").

248. Helicopteros Nacionales de Colom., S.A. v. Hall, 466 U.S. 408, 414 (1984) (footnote and citations omitted).

249. See supra text accompanying notes 142-43.

250. See Daimler v. Bauman, 134 S. Ct. 746, 764-65 (2014) (Sotomayor, J., concurring in the judgment).

251. The example she gave in both cases was Perkins, but as I have pointed out, it really is not an exception to the Goodyear-Daimler approach but rather is entirely consistent with it. See supra note 163. The Perkins Court itself pointed out the less than overwhelming nature of Benguet's forum contacts. See supra text accompanying note 96.

252. See General Motors Manufacturing Plants, GM AutH., http://gmauthority .com/blog/gm/gm-manufacturing/ (last visited Oct. 7, 2014).

253. Id. (Indiana, 2.85 million square feet on 716 acres; Kansas, 572 acres; Kentucky, 1 million square feet on 212 acres, Missouri, 3.7 million square feet; Ohio, 6 million square feet; Texas, 3.75 million square feet on 250 acres).

254. Id. (Indiana, 1986; Kansas, 1987; Kentucky, 1981; Missouri, 1983; Ohio, 1966; Texas, 1954). 
has 3,900 employees and produces one car every fifty-eight seconds. ${ }^{255}$ Goodyear-Daimler may suggest that such activities cannot support general jurisdiction, but justifying that result in terms of "contacts" seems absurd, especially when compared with either a place of incorporation with which the corporation has no other connection ${ }^{256}$ or an individual's temporary presence in a state.

There are two ways to attempt to resolve the absurdity. First, Goodyear and Daimler may have let the air out of Burnham's tires.257 Second, a more conservative approach would not take the Court's dicta seriously, leaving Burnham unimpaired. The three cases cannot, however, co-exist on the basis of "contacts." Goodyear and Daimler were easy cases ${ }^{258}$ once the Court declined to impute the contacts of the parent (Goodyear) or the subsidiary (Daimler) to the foreign defendant. That is why they are such weak support for a broader rule. The Court has never heard a general jurisdiction case involving the sort of systematic, continuous, and voluminous contacts that GM has with six states other than Michigan. ${ }^{259}$ One may speculate that the Court would find those contacts sufficient to serve as presence proxies, but one cannot know. If the Court would allow general jurisdiction, then Goodyear and Daimler stand as isolated cases, and their dicta become less important. If the Court would refuse jurisdiction, then Goodyear and Daimler have major case implications for general jurisdiction over individuals.

The Court has declared it inappropriate that corporations be subject to general jurisdiction in places not their "homes," apart from the forum contacts the corporation may have. There is nothing inherently unreasonable about that position; the unreasonableness is permitting states to exercise general jurisdiction over transient individuals. The imbalance between the Court's treatment of general jurisdiction with respect to corporations on one hand and individuals on the other is unseemly. The unreasonableness of transient jurisdiction becomes

255. See Fairfax Assembly Plan - Fairfax, Kansas, USA, GM Auth., http://gmau thority.com/blog/gm/gm-manufacturing/gm-fairfax-assembly/ (last visited July 10, 2014).

256. See supra note 226.

257. Ms. Eng suggested that conclusion after Goodyear. See Eng, supra note 165, at 849. I agree. Daimler's relative-contacts approach drives (so to speak) the point home. See infra notes $265-86$ and accompanying text.

258. See supra notes $145-61$ and accompanying text.

259. See supra notes $150-61$ and accompanying text. Professor Pielemeier suggests that Allstate Ins. Co. v. Hague, 449 U.S. 302 (1981) is such a case. See Pielemeier, supra note 28. Allstate arose "from a fatal Wisconsin accident involving individuals who, at the time of the accident, all resided in Wisconsin. The claim involved insurance coverage under an insurance policy delivered in Wisconsin." Pielemeier, supra note 28, at 985 (footnotes omitted). "There is no indication that Allstate objected to personal jurisdiction. It must have assumed a motion to dismiss on jurisdictional grounds would be denied, because although it had delivered the policy in Wisconsin (presumably from a Wisconsin office), it was 'doing business' in Minnesota." Id. (footnote omitted). 
more apparent when one applies to it the factors that, at least according to some scholars, are appropriate in considering general jurisdiction over foreign corporations. ${ }^{260}$

\section{A. General Jurisdiction Over the Individual}

Convenience for the defendant is minimal. By hypothesis, presence is temporary, and the plaintiff's claim is unrelated to the defendant's presence in the forum. Convenience for the plaintiff is, at best, mixed. The plaintiff chose the forum for some reason (for example, the plaintiff's residence) but the claim's unrelatedness will make the litigation more difficult because evidence and witnesses likely are not in the forum.

The state has a limited sovereignty interest because the claim has nothing to do with in-state activity. If the plaintiff is a state citizen, the state has some sovereignty interest. On the other hand, its sovereignty interest may clash with (1) the sovereignty interest of the state where the cause of action arose and (2) the sovereignty interest of the defendant's domicile.

Reciprocity is minimal because the defendant's presence is only temporary. No one today would quarrel with a forum's entitlement to exercise specific jurisdiction. However, it is one thing to tell the individual that presence in the forum allows the forum's courts to exercise personal jurisdiction with respect to forum activities but quite another to say that the individual's entire life is fair game for forum adjudication.

Professor Andrews' additional factor-predictability-is mixed as well. General jurisdiction is predictable in the abstract; if Burnham remains the law, individuals are on notice that any forum where they receive a summons may exercise jurisdiction over any claim. On the other hand, there is the unpredictability of never knowing whether one will receive service for such claims, as one travels from place to place.

\section{B. General Jurisdiction Over the Corporation}

Now consider the corporation that does regular business in a forum that is neither its state of incorporation nor its principal place of business. Apple boasts, "We have corporate offices all over the world, from Cupertino to London to Shanghai." 261 It is a California corpora-

260. See supra text accompanying note 167. Professor Brilmayer and her colleagues list (1) convenience for the defendant; (2) convenience for the plaintiff; (3) the forum state's sovereignty interest, and 4) reciprocal benefits and burdens. See Brilmayer, et al., supra note 167. Professor Andrews also includes predictability. See Andrews, supra note 27, at 1000.

261. See Jobs at Apple, ApPLE, Inc., https://www.apple.com/jobs/us/corporate.html (last visited Oct. 7, 2014). 
tion with its headquarters there. ${ }^{262}$ It has extensive worldwide operations. ${ }^{263}$ It operates retail stores worldwide, ${ }^{264}$ including ten stores in the New York City metropolitan area.

Considering the same factors applied to the transient individual, striking disparities appear. With respect to the defendant's convenience, it would be far easier for Apple to defend a claim unrelated to New York in that state than for (1) an individual tourist there for a week, (2) a family including a high school senior visiting Columbia University for a day, or (3) a New Jersey couple coming to the city one evening to see a Broadway play. There is no reason to anticipate disparity in convenience for the plaintiff or in New York's sovereignty interest.

Reciprocity presents the starkest contrast. ${ }^{265}$ The individual traveler receives benefits from New York: access to its historical sites and theaters, police, fire, sanitation and emergency medical services, and public transportation. Apple, operating continuously in New York, benefits from these same services, not merely for an evening, a day or a week, but every day of every year. It benefits from access to New York's resident, commuter and tourist population. The benefits Apple receives from New York far outstrip the transient individuals. ${ }^{266}$

262. See Apple, Inc., Annual Report (September 28, 2013), http://files.shareholder .com/downloads/AAPL/3351394991x0x701402/A406AD58-6BDE-4190-96A1-4CC2D 0D67986/AAPL_FY13_10K_10.30.13.pdf (Sept. 28, 2013) (last visited Oct. 7, 2014) (state of incorporation). See also Jobs at Apple, ApPLE, Inc., https:/www.apple.com/ about/ (last visited Oct. 7, 2014) (corporate headquarters).

263. See Apple, Inc., Annual Report (September 28, 2013) at 2, http://files.sharehol der.com/downloads/AAPL/3351394991x0x701402/A406AD58-6BDE-4190-96A1-4CC 2D0D67986/AAPL_FY13_10K_10.30.13.pdf (last visited Oct. 7, 2014).

The Company manages its business primarily on a geographic basis. Accordingly, the Company determined its reportable operating segments, which are generally based on the nature and location of its customers, to be the Americas, Europe, Japan, Greater China, Rest of Asia Pacific, and Retail. The Americas segment includes both North and South America. The Europe segment includes European countries, as well as India, the Middle East and Africa. The Greater China segment includes China, Hong Kong and Taiwan. The Rest of Asia, Pacific segment includes Australia and Asian countries, other than those countries included in the Company's other operating segments. The Retail segment operates Apple retail stores in 13 countries, including the U.S. Each operating segment provides similar hardware and software products and similar services. The results of the Company's geoId. graphic segments do not include results of the Retail segment.

264. See id. at 5.

265. Ms. Eng suggests that "The Supreme Court's citation of Brilmayer's article may signal a preference for the reciprocal benefits and burdens theory as the strongest justification for the application of general jurisdiction and an endorsement of domicile as the exclusive basis for general jurisdiction over individuals." Eng, supra note 165 , at 865 .

266. Both types of defendants also bear the burdens of being in New York, but it is safe to assume that the benefits outweigh the burdens; otherwise rational behavior would avoid New York. 
One final reciprocity comparison graphically underlines the disparity. In Burnham, Justice Brennan discussed reciprocity for the individual:

Subject only to the doctrine of forum non conveniens, an out-ofstate plaintiff may use state courts in all circumstances in which those courts would be available to state citizens. Without transient jurisdiction, an asymmetry would arise: a transient would have the full benefit of the power of the forum State's courts as a plaintiff while retaining immunity from their authority as a defendant. ${ }^{267}$

Transient jurisdiction enforces that reciprocity against the individual: Goodyear and Daimler erase it with respect to corporations. ${ }^{268}$

Would the Court allow general jurisdiction in those three transient individuals and over Apple, assuming service in the forum? With respect to the individuals, Burnham says general jurisdiction exists. With respect to Apple, Goodyear and Daimler muddy the waters. They seem to cut against general jurisdiction over Apple. ${ }^{269}$ Daimler trumpets the Court's dissatisfaction with the doing-business approach to general jurisdiction. ${ }^{270}$ Yet, Goodyear seemed to contemplate general jurisdiction based on "continuous and systematic" in-state corporate activity. ${ }^{271}$ Perhaps that is a reason not to take Goodyear seriously_or at least literally_in cases involving extensive corporate forum activity and not requiring imputation of contacts. Apple is doing business in New York. Goodyear and Daimler leave open the question of whether Apple's activities exceed simply "doing business" enough to qualify for general jurisdiction - that is, to make Apple "essentially at home." So much for predictability.

In contacts terms, the comparison between Apple and the individuals is not even close. Apple has continuous and systematic contacts with New York. The individuals have isolated contacts. It will be difficult for the Court to explain why it is consistent with due process to exercise general jurisdiction over the individuals but not over Apple.

267. Burnham v. Superior Ct., 495 U.S. 604, 638 (1990) (citation omitted). But see Adam v. Saenger, 303 U.S. 59 (1938) (permitting jurisdiction by counterclaim over non-resident plaintiff otherwise immune from jurisdiction and thus re-establishing reciprocity in that respect).

268. See Goodyear Dunlop Tires Operations, S.A. v. Brown, 131 S. Ct. 2846 (2011); Daimler AG v. Bauman, 134 S. Ct. 746 (2014). That may not be the asymmetry that Justice Brennan had in mind, but if one substitutes "corporation" for the second occurrence of "transient" in the quotation, the asymmetry is just as troubling. Burnham, 495 U.S. at 638.

269. Perkins, which the Court characterizes as the extraordinary case for which general jurisdiction exists away from the diversity loci really is not, because of the relocation, albeit temporary, of Benguet's principal place of business. See Perkins v. Benguet Consol. Mining Co., 342 U.S. 437, 447-48 (1952).

270. See Daimler, 134 S. Ct. at 762 n.20. See also supra text accompanying note 133.

271. See Goodyear, 131 S. Ct. at 2851 ("continuous and systematic affiliation"). See also id. at 2857 ("'the continuous and systematic general business contacts' necessary to empower North Carolina to entertain suit against them on claims unrelated to anything that connects them to the State"). 
Professor Brilmayer and her colleagues suggested considering whether "the defendant reaches the quantum of activity in which a purely local company would engage." 272 Apple satisfies that test in New York. Transient individuals will rarely reach that level.

It is inconceivable that the individuals are "essentially at home" in New York. Goodyear and Daimler make it unclear whether the Court would characterize Apple as "essentially at home" there, given the Court's concern about universal general jurisdiction over large corporations. "A corporation that operates in many places can scarcely be deemed at home in all of them. Otherwise, 'at home' would be synonymous with 'doing business' tests framed before specific jurisdiction evolved in the United States."273 The Goodyear and Daimler Courts appear less concerned with universal general jurisdiction over peripatetic individuals.

Daimler's introduction of relative contacts makes the Court's anomalous treatment of corporations and individuals for purposes of general jurisdiction even harder to accept. All of the individuals mentioned above have "a 'far larger quantum of . . . activity' having no connection to any in-state activity" 274 than they have in-state activity. The parallel to Daimler's argument is unmistakable. "Nothing in International Shoe and its progeny suggests that 'a particular quantum of local activity' should give a State authority over a 'far larger quantum of ... activity' having no connection to any in-state activity." 275 If a corporation does not open its entire corporate life for forum adjudication by doing business in a state, it cannot be consistent with due process for a transient individual to open his entire life to forum adjudication.

If the Court still believes that reasonableness has some role to play in constitutional jurisdiction, ${ }^{276}$ it must either ignore reasonableness

272. Brilmayer et al., supra note 106 , at 742 .

273. See Daimler, 134 S. Ct. at 762 n.20. See also id. at 760-61 (citation omitted) ("Plaintiffs would have us look beyond the exemplar bases Goodyear identified, and approve the exercise of general jurisdiction in every State in which a corporation 'engages in a substantial, continuous, and systematic course of business.' . . . . That formulation, we hold, is unacceptably grasping").

274. Id. (quoting Feder, supra note 48, at 694).

275. Id. See supra note 133 and accompanying text.

276. Note, however, that the Court eschewed the reasonableness inquiry in Daimler:

The majority evidently agrees that, if the reasonableness prong were to apply, it would be unreasonable for California courts to exercise jurisdiction over Daimler in this case. See ante, at 761-62 (noting that it would be "exorbitant" for California courts to exercise general jurisdiction over Daimler, a German defendant, in this "Argentina-rooted case" brought by "foreign plaintiffs"). But instead of resolving the case on this uncontroversial basis, the majority reaches out to decide it on a ground neither argued nor decided below.

Daimler, 134 S. Ct. at 765 (Sotomayor, J., concurring in the judgment) (citation and footnote omitted). 
entirely when considering jurisdiction over transient individuals or assert it only as an ipse dixit. The explanation that we have always done things that way is unpersuasive. ${ }^{277}$ Justice Holmes observed,

It is revolting to have no better reason for a rule of law than that so it was laid down in the time of Henry IV. It is still more revolting if the grounds upon which it was laid down have vanished long since, and the rule simply persists from blind imitation of the past. ${ }^{278}$

If there is a justification for transient jurisdiction other than blind imitation of the past, ${ }^{279}$ no one has articulated it.

There is another reason to be skeptical about regarding past practice as strong support for the continuation of transient jurisdiction. Modern procedure had not developed; civil arrest-or its equivalent in the form of seizure of the defendant's property-was the only way to begin a case. ${ }^{280}$ However, to paraphrase International Shoe, the ca-

277. In Burnham, Justice Brennan argued in favor of jurisdiction based on the defendant's having enjoyed the benefits and protections of California law during his three days there. It is inconceivable that Justice Brennan's mode of analysis would have led him to concur in either Goodyear or Daimler. Giant corporations operating in the forum receive far more benefits and protections than an individual sojourning for three days ever could. Recall that Justice Brennan dissented on general-jurisdiction in Helicopteros, though acknowledging the plausibility of the majority's view. See Helicopteros Nacionales de Colom., S.A. v. Hall, 466 U.S. 408, 419 (1984); see also supra text accompanying note 154 .

278. Oliver W. Holmes, Justice of the Supreme Judicial Court of Mass., Address, The Path of the Law, 10 Harv. L. Rev. 457, 469 (1897). Shaffer v. Heitner, 433 U.S. 186, 212 (1977) (quoting Int'l Shoe, 326 U.S. at 316), expressed the same view less bluntly: “'[T]raditional notions of fair play and substantial justice' can be as readily offended by the perpetuation of ancient forms that are no longer justified as by the adoption of new procedures that are inconsistent with the basic values of our constitutional heritage."

279. There is an unstated assumption underlying the argument based solely on history: that such cases are examples of what today the Court refers to as general jurisdiction. There is no evidentiary support for such an assumption. Perhaps cases in courts outside the defendant's domicile were predominantly cases that today would be specific-jurisdiction cases, as Professor Twitchell argued. See Twitchell, supra note 146, at 618 ("Despite the power-based nature of jurisdiction doctrine, . . . courts did not completely ignore the nature of the cause of action and only occasionally decided disputes having no relationship with the forum."). If that is so, history's support for transient is at least partly illusory.

280. Not until the eighteenth century did the capias give way to the summons, and that change came about not through the common law, but by statutes that forbade using capias in cases of lesser value. See Hazard, supra note 164, at 248 n.19. That so many statutes (Professor Hazard listed eight) were necessary demonstrates the ubiquity of the capias. Reliance on the capias was so fixed that early cases held that one could not sue corporations in tort, there being no way to execute the writ. See Meares v. Comm'rs of Wilmington, 31 N.C. 73, 78 (1948). But see Denver \& Rio Grande Ry. Co. v. Harris, 122 U.S. 597 (1887) (quoting State v. Morris \& Essex R.R. Co., 23 N.J.L 369 (1852)):

"[I]t is now perfectly well settled, contrary to the ancient authorities, that a corporation is liable civiliter for all torts committed by its servants or agents by authority of the corporation, express or implied .... The result of the modern cases is that a corporation is liable civiliter for torts committed by its servants or agents precisely as a natural person; and that it is liable as a 
pias ad respondendum "has given way to personal service of the summons or other form of notice." 281 That procedural shift means that the grounds underlying the capias ad respondendum "have vanished long since. . .."282 Perhaps nothing demonstrates this better than the proliferation of state statutes allowing extraterritorial service. ${ }^{283}$

Consider Burnham again. ${ }^{284} \mathrm{Mr}$. Burnham was in California on business for three days. While there, he received service of process in a divorce action, and the unanimous Court ruled that jurisdiction existed simply by that fact. Suppose that Mr. Burnham had received service of process at his home in New Jersey "by first-class mail, postage prepaid, requiring a return receipt." 285 It is almost unthinkable ${ }^{286}$ that a unanimous Court still have said that California jurisdiction existed on the divorce claim. On the other hand, it is highly unlikely that today's Court, following the rationale of Goodyear and Daimler, will overrule the unanimous decision in Burnham, barely twenty-five years old, although only Justices Scalia and Kennedy remain on the Court from that time. The third possibility is that the Court will follow Goodyear and Daimler with respect to corporations and Burnham with respect to individuals. That would require the Court to explain

\footnotetext{
natural person for the acts of its agents done by its authority, express or implied, though there be neither a written appointment under seal, nor a vote of the corporation constituting the agency or authorizing the act." Denver, 122 U.S. at 597 (quoting Morris, 23 N.J.L 369).

281. Int'l Shoe Co. v. Washington, 326 U.S. 310, 316 (1945).

282. See Holmes, supra note 278, at 469 (emphasis added).

283. See, e.g., Cal. Civ. Proc. $\$ 415.40$ (West 2004); N.Y. C.P.L.R. 313 (Consol. 1999).

284. See supra notes $210-223$ and accompanying text.

285. Cal. Civ. Proc. $\$ 415.40$.

286. In Burnham, Justice Scalia criticizing Justice Brennan's reasonableness analysis that rested on Mr. Burnham's having benefited from his three days in California, deemed the possibility beyond discussion:

Three days' worth of these benefits strike us as powerfully inadequate to establish, as an abstract matter, that it is "fair" for California to decree the ownership of all Mr. Burnham's worldly goods acquired during the 10 years of his marriage, and the custody over his children. We daresay a contractual exchange swapping those benefits for that power would not survive the "unconscionability" provision of the Uniform Commercial Code. Even less persuasive are the other "fairness" factors alluded to by Justice Brennan. It would create "an asymmetry," we are told, if Burnham were permitted (as he is) to appear in California courts as a plaintiff, but were not compelled to appear in California courts as defendant; and travel being as easy as it is nowadays, and modern procedural devices being so convenient, it is no great hardship to appear in California courts. . . . In other words, even if one agreed with Justice Brennan's conception of an equitable bargain, the "benefits" we have been discussing would explain why it is "fair" to assert general jurisdiction over Burnham-returned-to-New-Jersey-after-service only at the expense of proving that it is also "fair" to assert general jurisdiction over Burnham-returned-to-New-Jersey-without-service-which we know does not conform with "contemporary notions of due process.

Burnham v. Superior Court, 49 U.S. 604, 623-24 (1990) (Scalia, J., concurring in the judgment).
} 
why corporations should receive more immunity from general jurisdiction than individuals do. The disparity should be unthinkable; cognitive dissonance should forbid it.

Consider one last hypothetical. Under Burnham, an individual who performs a single lawful act in a state is subject to general jurisdiction if he receives process while there, even if that visit was his only contact with the state, and the single act was entirely lawful. On the other hand, if the individual never goes to the state, but his agent goes and performs the same single, lawful act, the individual is not subject to general jurisdiction even if the agent receives service of process in the same action against the individual. It is difficult to explain the divergent results in due process terms, except on Justice Scalia's historical theory.

That may be difficult, but it is quite impossible to explain the results in Daimler's relative-contacts terms. In the first variation the individual was in the forum only once, and in the second he spent his entire life outside the forum. Perhaps the Court would seek to turn aside this criticism on the ground that "corporations are different." That merely begs the question of why, for purposes of general jurisdiction, they are different. None of the Court's jurisprudence of personal jurisdiction, from Pennoyer to Daimler, answers that question.

\section{Conclusion}

In the aftermath of Shaffer v. Heitner, ${ }^{287}$ some courts ${ }^{288}$ and scholars recognized its potential to undermine transient jurisdiction, and

287. See generally Shaffer v. Heitner, 433 U.S. 186 (1977).

288. See, e.g., Nehemiah v. Athletics Conference of the U.S.A., 765 F.2d 42, 47 (3d. Cir. 1985):

If the mere presence of property cannot support quasi in rem jurisdiction, it is difficult to find a basis in logic and fairness to conclude that the more fleeting physical presence of a non-resident person can support personal jurisdiction. . . We conclude therefore that neither logic nor history supports personal jurisdiction over an unincorporated association solely on the basis of service on its agent within the forum.

See also Harold M. Pittman Co. v. Typecraft Software Ltd., 626 F. Supp. 305, 312-13

(N.D. Ill. 1986):

We now hold that, under Shaffer, mere service of process upon a defendant transiently present in the jurisdiction does not vest a state with personal jurisdiction over the defendant. Personal service within the jurisdiction is not the litmus test for proper in personam jurisdiction. Rather, the test is whether the defendant has had minimum contacts with the forum "such that maintenance of the suit does not offend traditional notions of fair play and substantial justice."

....

Were the court to hold that minimum contacts need not be present for an exercise of in personam jurisdiction over a defendant present in the jurisdiction when served, the court would thereby accord less protection to an individual defendant than to his or her property within the state. Surely the Shaffer Court did not intend such an illogical and unfair result. 
more than one scholar questioned its foundation. ${ }^{289}$ "Indeed, the Pennoyer notion that state power extends to all defendants physically within the forum may have perished in Shaffer $v$. Heitner, in which the Supreme Court held that all assertions of state jurisdiction must satisfy the standard of fairness based on minimum contacts set forth in International Shoe." 290 Nonetheless, two years after that statement, Burnham v. Superior Court ${ }^{291}$ delivered a unanimous endorsement of transient jurisdiction (to the dismay of the academy ${ }^{292}$ ), albeit without a majority rationale.

Goodyear and, particularly, Daimler undermine Burnham. Some lower courts and scholars ${ }^{293}$ have attributed that effect to Goodyear. Giraldo v. Drummond Company, Inc. ${ }^{294}$ explicitly applied Goodyear's essentially-at-home approach, refusing to find general jurisdiction and noting that a defendant's presence in the forum would be insufficient

But see Amusement Equip., Inc. v. Mordelt, 779 F.2d 264, 268 (5th Cir. 1985) (footnote omitted):

The source of the commentators' gloom rests principally on the following statement in Shaffer. "We therefore conclude that all assertions of statecourt jurisdiction must be evaluated according to the standards set forth in International Shoe and its progeny." ... ([E]mphasis added). We concede that this sweeping assertion undermines the correspondingly categorical claim that "[i]t has long been black letter law that personal service within its geographical area establishes a court's personal jurisdiction over the defendant." ... However, while Shaffer may have rendered the black letter gray, we do not think the letter of the law has become so pale that it can be read only with conjurer's glasses.

Accord, Driver v. Helms, 577 F.2d 147, 156 n.25 (1st Cir. 1978), rev'd on other grounds sub. nom. Stafford v. Briggs, 444 U.S. 527 (1980) ("[I]f a defendant is found and served within the state, minimum contacts need not be established, and jurisdiction may be asserted on the basis of the state's sovereignty."); Opert v. Schmid, 535 F. Supp. 591, 593-94 (S.D.N.Y. 1982); Aluminal Indus., Inc. v. Newtown Commercial Assocs., 89 F.R.D. 326, 329 (S.D.N.Y. 1980).

289. See, e.g., Restatement (SEcond) of Conflict of Laws § 5, cmt. a (1982) (expressing doubt with respect to transient jurisdiction after Shaffer); 4 WRIGHT \& MiLleR, supra note 48, § 1067.1, at 430 (2002) (“[T]he Court's conclusion appeared to bring into question the continued validity of jurisdiction secured by 'tagging." "); Rhonda Wasserman, The Subpoena Power: Pennoyer's Last Vestige, 74 Minn. L. Rev. 37, 99-100 (1989) ("Read together, Ireland [Insurance Corp. of Ireland v. Compagnie des Bauxites de Guinee, 456 U.S. 694 (1982)] and Shaffer render suspect the proposition that a state necessarily has unrestrained power over all persons served while physically present within its territory, and even over all domiciliaries, regardless of the amount of ongoing contact they have with the state."); Daniel O. Bernstine, Shaffer v. Heitner: A Death Warrant for the Transient Rule of In Personam Jurisdiction?, 25 VILl. L. ReV. 38, 54 (1979).

290. Brilmayer et al., supra note 106, at 749 (footnote omitted).

291. Burnham, 495 U.S. 604 (1990).

292. See, e.g., Robert Taylor-Manning, An Easy Case Makes Bad Law-Burnham v. Superior Court of California, 110 S. Ct. 2105 (1990), 66 WAsh. L. Rev. 623, 623 (1991).

293. See Eng, supra note 165, at 849 (arguing that transient jurisdiction should no longer be available); Pielemeier, supra note 28, at 991 (same).

294. Giraldo v. Drummond Co., No. 2:09-CV-1041-RDP, 2012 WL 2358306, at *7-8 (N.D. Ala. June 20, 2012). 
"even if [he] stayed in Alabama for weeks at a time. . . Coming to Alabama for the sake of his employment is vastly at odds with being "essentially at home' in Alabama." 295 Other courts have also used the Goodyear approach. ${ }^{296}$ "General jurisdiction based on contacts is an integral part of minimum contacts analysis, and it seemingly should apply to individuals, just as the specific jurisdiction component does." 297 Both cases antedate Daimler's reaffirmation of Goodyear's essentially-at-home test and introduction of the relative-contacts approach, making its centrality to general jurisdiction analysis unmistakable.

If the constitutional test for general jurisdiction is "essentially at home," transient jurisdiction cannot stand. If the Court would try to save it, it can do so only on the ground that it is a practice so long recognized; ${ }^{298}$ nothing other than history's dead hand appears to support it. As I said at the outset, something has got to give.

295. $I d$

296. See, e.g., Ford v. Mentor Worldwide, LLC, No. 13-6317, 2014 WL 693926, at *8 (E.D. La. Feb. 21, 2014) (reading Goodyear to require that an individual defendant "is fairly regarded as at home in the forum state"); Red Strokes Entm't, Inc. v. Sanderson, No. 3:12-CV-0008, 2012 WL 1514892 (M.D. Tenn. May 1, 2012).

297. Andrews, supra note 27, at 1055.

298. See supra notes $217-218$ and accompanying text. But jurisdiction over corporations based on substantial contacts with the forum (before International Shoe under the banner of "corporate presence") was long established as well. See, e.g., Phila. \& Reading Ry. Co. v. McKibbin, 243 U.S. 264, 265 (1917) ("A foreign corporation is amenable to process to enforce a personal liability, in the absence of consent, only if it is doing business within the State in such manner and to such extent as to warrant the inference that it is present there."); Barrow S.S. Co. v. Kane, 170 U.S. 100, 109, 111 (1898) (recognizing "doing business" as a predicate for jurisdiction over a corporation, even when the action was unrelated to the forum). 